\title{
The Glacial History of the Pindus Mountains, Greece
}

\author{
P. D. Hughes, J. C. Woodward, P. L. Gibbard, ${ }^{1}$ M. G. Macklin, ${ }^{2}$ \\ M. A. Gilmour, ${ }^{3}$ and G. R. Smith ${ }^{4}$ \\ Geography, School of Environment and Development, University of Manchester, \\ Oxford Road, Manchester M13 9PL, United Kingdom \\ (e-mail: philip.hughes@manchester.ac.uk)
}

\begin{abstract}
A B S T R A C T
Geomorphological evidence for Pleistocene glaciation has been mapped in the Pindus Mountains of northwest Greece, and the chronology of glaciation in this area has been established through soil profile analysis and U-series dating of secondary carbonates (calcite) formed within glacial deposits. Three glacial stages are evident in the sedimentological and geomorphological records. The earliest and most extensive recorded glaciation predates 350,000 yr B.P. and was characterized by extensive valley glaciers and ice fields. A more recent glaciation occurred before the last interglacial and was characterized by glaciers that reached midvalley positions. The last phase of glaciation in Greece is recorded by small cirque glacier moraines and relict periglacial rock glaciers. The glacial and periglacial sequence on Mount Tymphi has been used in conjunction with a reference parastratotype, the long lacustrine sequence at Ioannina, to provide a chronostratigraphical framework for cold-stage deposits in Greece. The three glacial stages are formally defined: the Skamnellian Stage, equivalent to the Elsterian Stage of northern Europe and marine isotope stage (MIS) 12; the Vlasian Stage, equivalent to the late Saalian Stage of northern Europe and MIS 6; and the Tymphian Stage, which is equivalent to the Weichselian/Würmian stages of northern Europe and the Alps, respectively, and MIS 5d2. This is the first formalized chronostratigraphical framework based on the glacial record to be established for cold stages in the Mediterranean and provides a new platform for paleoclimatological investigations in the region.
\end{abstract}

Online enhancement: table.

\section{Introduction}

One of the earliest articles reporting evidence of glaciation in Greece was by Niculescu (1915), who noted the moraines and cirques on Mount Smolikas in the northern Pindus Mountains. Later researchers reported glacial features elsewhere in this region (Sestini 1933; Mercer 1963), as well as in areas further south in Greece (Mistardis 1952; Pechoux 1970). More recently, glacial research has been pub-

Manuscript received October 11, 2005; accepted March 7, 2006.

${ }^{1}$ Cambridge Quaternary, Department of Geography, University of Cambridge, Downing Place, Cambridge CB2 3EN, United Kingdom.

${ }^{2}$ Institute of Geography and Earth Sciences, Llandinum Building, Penglais Campus, University of Wales, Aberystwyth, Ceredigion SY23 3DB, Wales, United Kingdom.

${ }^{3}$ Department of Earth Sciences, Open University, Walton Hall, Milton Keynes MK7 6AA, United Kingdom.

${ }^{4}$ Department of Environmental and Geographical Sciences, Manchester Metropolitan University, Chester Street, Manchester M15 GD, United Kingdom. lished from the uplands of the Peloponnese (Mastronuzzi et al. 1994), Mount Olympus (Smith et al. 1997), Mount Smolikas (Boenzi et al. 1992), and Mount Tymphi (Palmentola et al. 1990; Woodward et al. 1995; Smith et al. 2000; Woodward et al. 2004; fig. 1).

The timing of Pleistocene glaciation in Greece remained unknown until recently, when Woodward et al. (2004) presented uranium-series (Useries) dates from secondary carbonates formed in glacial deposits on Mount Tymphi. These dates showed that the earliest glacial deposits formed before 350,000 yr B.P. and that a later phase of glaciation took place before the last interglacial. This represented a marked shift from the common view for Greece put forward by many workers that the glacial sequences formed during the last glacial stage (Weichselian/Würmian; e.g., Messerli 1967; Palmentola et al. 1990; Boenzi and Palmentola 1997). 


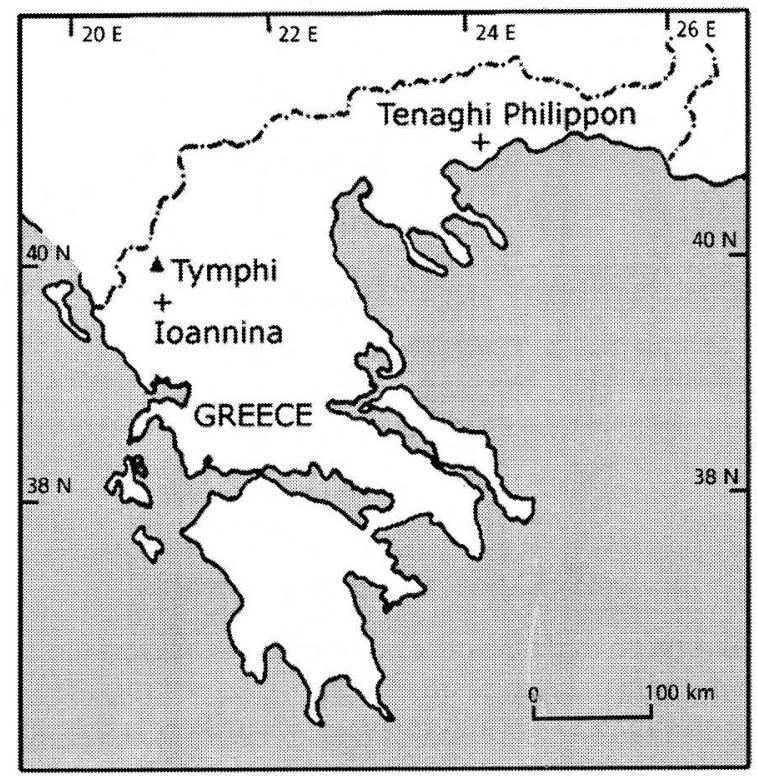

Figure 1. Map of Greece showing the position of Mount Tymphi and the long Quaternary stratigraphical sequences of Tenaghi Philippon and Ioannina.

A Middle Pleistocene age for the most extensive glaciations has also been proposed for Mount Olympus, in northeastern Greece. Smith et al. (1997) tentatively placed glacial units during intervals equivalent to marine isotope stages (MIS) 8, 6, and 4-2, although no radiometric dates were available for the Olympus glacial sequence. Confirmation of a Middle Pleistocene glacial record in Greece by Woodward et al. (2004) is in accord with radiometrically dated sequences recently reported elsewhere in the Mediterranean, such as in Portugal and Spain (Fernandez Mosquera et al. 2000; Kotarba et al. 2001). These recent discoveries have confirmed suggestions of Middle Pleistocene glacial records in the Mediterranean made several decades ago by workers such as Barrère (1963), Alimen (1964), and Federici (1980).

This article presents an analysis of the glacial and periglacial sequence in the northern Pindus Mountains. For the first time, a geochronological framework using radiometric dating is combined with detailed morpho-lithostratigraphical and pedogenic data to reconstruct the glacial history of Greece. Glacial units are then used to define chronostratigraphical cold stages in Greece in conjunction with a parastratotype-the continuous Middle and Late Pleistocene pollen stratigraphical record at Ioannina (Tzedakis 1994; Tzedakis et al. 2002).

\section{Study Area}

This article focuses on the glacial record of Mount Tymphi (2497 m a.s.l.) in Epirus, northwest Greece (fig. 1). This mountain is situated in the northern Pindus Mountains and is formed largely in Paleocene-Eocene limestone, with some exposures of Senonian-Jurassic dolomites and limestones (IGME 1970; Bailey et al. 1997). The lower slopes are dominated by younger flysch rocks (Late Eocene to Miocene), which consist of thin $(10-20 \mathrm{~cm})$ beds of graded sandstones intercalated with softer, fissile siltstones (Lewin et al. 1991; Woodward et al. 1992). Karstic features such as dolines, pavements, vertical shafts, and extensive cave systems are well developed all over the mountain (Waltham 1978), and Pleistocene glacial deposits and landforms are exceptionally well preserved, a situation promoted by karstic drainage and widespread cementation of moraines (Woodward et al. 2004).

\section{Field and Laboratory Methods}

Field Methods. The glacial geomorphology of Mount Tymphi was mapped onto $1: 25,000$ topographic base maps. Sediment units were systematically described and subdivided using litho- and morphostratigraphical criteria (cf. Hughes et al. 2005). Detailed sediment analyses were undertaken at section exposures in road cuttings, aggregate quarries, and in natural stream-cut sections (Hughes et al., forthcoming $b$ ). The weathering characteristics of soils developed on glacial sediments were also employed to differentiate between surfaces of differing age and to aid correlation between stratigraphical sequences in different cirquevalley systems. Soils form during periods of geomorphological stability and, in Mediterranean environments, may continue to develop over lengthy periods, allowing soils to reach advanced levels of maturity (Woodward et al. 1994; van Andel 1998). A range of soil properties were determined, including rubification, clay film, texture, structure, dry consistency, moist consistency, color value, and $\mathrm{pH}$ (e.g., Harden 1982; Birkeland 1999). These were quantified to derive for each site the profile development index described in Harden (1982). In order to examine whether the relationship between soil weathering and moraine age was affected by altitude, glacial units and associated soil profiles were sampled at a range of altitudes in different cirque-valley systems.

Geochronological Methods. Radiometric dating was applied to further test intervalley stratigraphical correlations and to establish the position of 
glacial sedimentary units in time. The absence of reliable geochronologies is one of the major obstacles to understanding the glacial records in the Mediterranean region (Hughes et al., forthcoming b). Fortunately, in many areas on Mount Tymphi, secondary carbonates have formed within glacial deposits, and these can be dated by U-series methods. In glacial systems, the subglacial transport of carbonate rock debris produces abundant fine reactive particles (rock flour) that are susceptible to dissolution and reprecipitation as secondary carbonates (Fairchild et al. 1994). This feature was successfully utilized by Woodward et al. (2004) to provide minimum ages for glacial deposits on Mount Tymphi using U-series dating. This approach has also been applied to secondary carbonates within glacial deposits in the Gran Sasso area of the Italian Appenines by Kotarba et al. (2001) and appears to be one of the most useful methods of dating glacial deposits in areas dominated by carbonate lithologies.

While morphostratigraphical position, supported by pedostratigraphical evidence, is the fundamental criterion for establishing the relative age of the glacial sedimentary units, the U-series dates were used to bracket these units in time. Dated secondary carbonates provide minimum ages for the host sediments. Thus, it is important to appreciate that the estimated age of the host glacial sediments is based on the oldest ages obtained from secondary carbonates in a given glacial sedimentary unit. Phases of secondary carbonate formation can take place long after the deposition of the host sediments, and various calcites may form at a range of different times. Thus, multiple samples from any given stratigraphical unit should be dated in order to understand the history of secondary carbonates formation, as demonstrated by Woodward et al. (2004). In addition, a large sample of secondary carbonate ages from neighboring valley formations should be considered when constructing a geochronology for any particular group of sediments.

All sampled secondary carbonates were examined for evidence of open-system behavior before analysis using both a hand lens and high-power microscopy. Where multiple growth layers were present, samples were taken from discrete crystal layers. Chemical preparation and isotope measurements were undertaken at the United Kingdom Natural Environment Research Council Uranium Series Facility at the Open University using standard techniques (cf. Edwards et al. 1987; van Calsteren and Schwieters 1995). Samples were totally dissolved and spiked with ${ }^{236} \mathrm{U}$ and ${ }^{229} \mathrm{Th}$ tracers, and the $\mathrm{U}$ and $\mathrm{Th}$ fractions were purified using stan- dard techniques (Edwards et al. 1987). Samples were loaded onto graphite-coated rhenium filaments and analyzed by thermal ionization mass spectrometry (TIMS).

\section{Morpho-lithostratigraphical Results}

Mount Tymphi is one of the most extensively glaciated mountains of the Pindus range, and it constitutes one of the finest examples of a Mediterranean glacio-karst landscape. Detailed results and a discussion of the glacial sedimentology are presented in Hughes et al. (forthcoming $a$ ). Stratigraphical subdivisions of glacial (and periglacial) units are summarized in figure 2 with letters used to denote stratigraphical units. The capital letter of the stratigraphical unit code denotes the formation (e.g., $\mathrm{A}=$ Tsepelovo Formation). The number represents members within formations, in stratigraphical order (e.g., A1 = Tsepelovo Formation; Voidomatis member). Where multiple time-equivalent member units occur within a formation, members are differentiated by a lowercase letter (e.g., units A3a, A3b, A3c).

Tsepelovo and Skamnelli Formations. Three stratigraphical units are present in two separate valleys that contain the villages of Tsepelovo and Skamnelli on the southern slopes of Mount Tymphi (figs. 4-6). The lowest stratigraphical unit is characterized by diamicts and associated surface ridge forms. Detailed sedimentological analyses have shown that the sediments represent a range of subglacial and meltout facies, which formed close to the margins of oscillating valley glaciers (Hughes et al., forthcoming $a$ ). These deposits are assigned to the Voidomatis (A1) and Kato Radza (B1a) members below Tsepelovo and Skamnelli, respectively (figs. 4, 5). These deposits display evidence of prolonged weathering, and deep red soils have formed on them (fig. 3B). Similar deposits also occur to the east of Skamnelli, down to ca. $1100 \mathrm{~m}$ a.s.l. (Megali Rachi member; B1b; fig. 5).

In the valleys above Tsepelovo and Skamnelli, midvalley moraines are exceptionally well preserved and occur down to ca. $1600-1700 \mathrm{~m}$ a.s.l. These deposits are assigned to the Laccorponti member (A2) in the Tsepelovo Formation (fig. 4) and the Vourtapa (B2a), Vrichos (B2b), and Tsioumako (B2c) members in the Skamnelli Formation to the east (fig. 5). Multiple moraine crests are present, and these are closely spaced, arcuate, and often littered with large subrounded boulders (fig. $3 C$ ). Inside and up-valley of these moraines, limestone pavements are well developed (Woodward et al. 2004) and often form a steplike profile known 


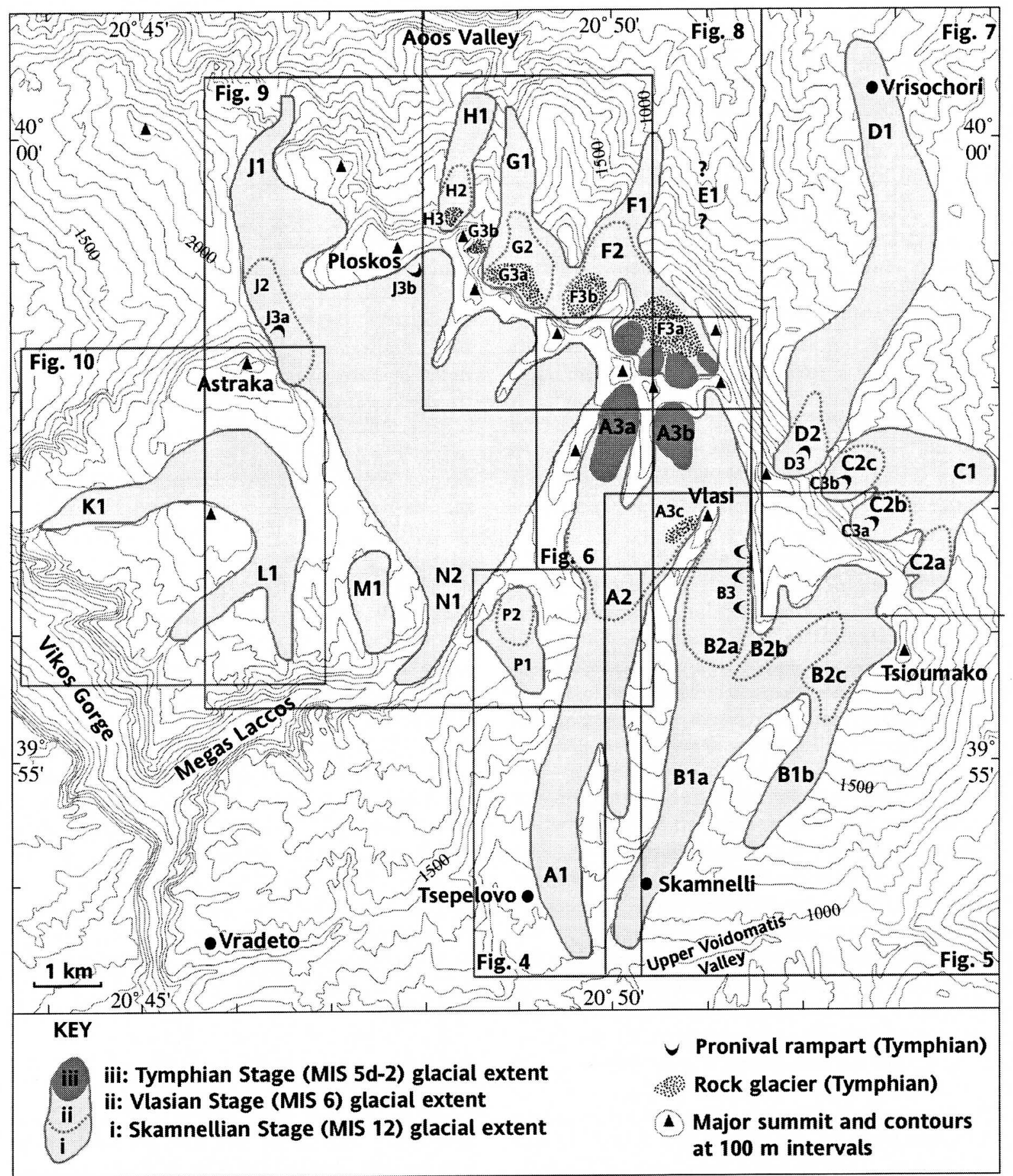

Figure 2. Extent of glaciation on Mount Tymphi and the coverage of the geomorphological maps. Letter codes indicate stratigraphical units described in the text and denoted on detailed geomorphological maps.

as Schichttreppenkarst (cf. Bögli 1964, 1980; Sweeting 1972).

The highest deposits of the Tsepelovo and Skamnelli areas occur in the highest valley areas, in cirques and at the base of steep slopes, and are clearly separated from the lower moraines. Their composition is dominated by large subrounded boulders. In the Laccos Tselon and Laccos Megalon Litharion cirques (fig. 6), moraine ridges delimit the termini of small former glaciers (Tselon and Lith- 
A.

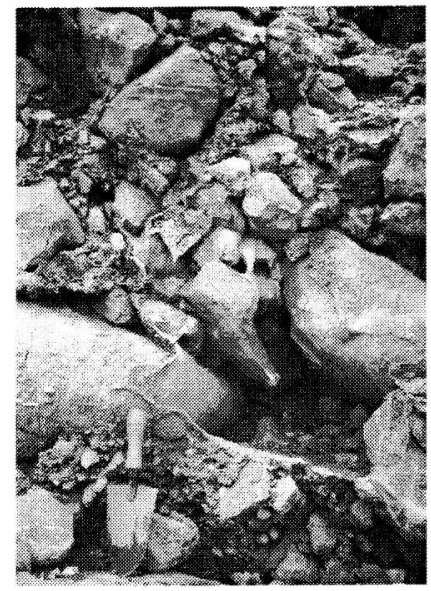

B.

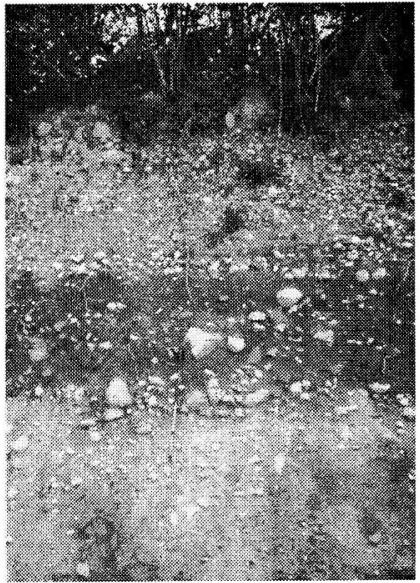

C.

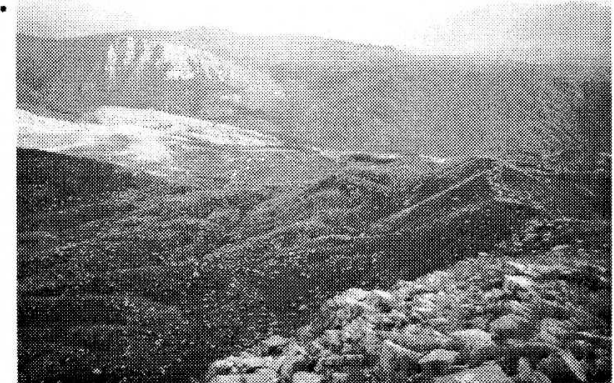

D.

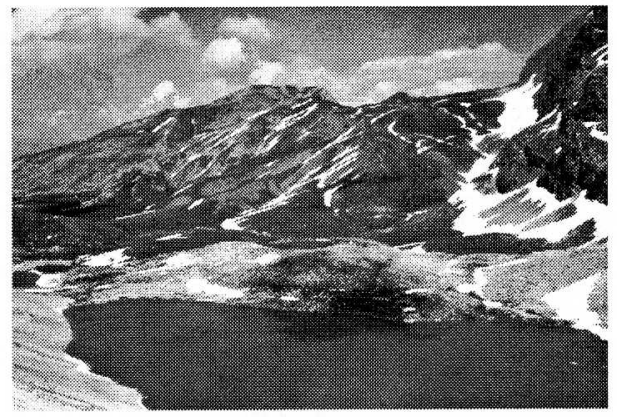

E.

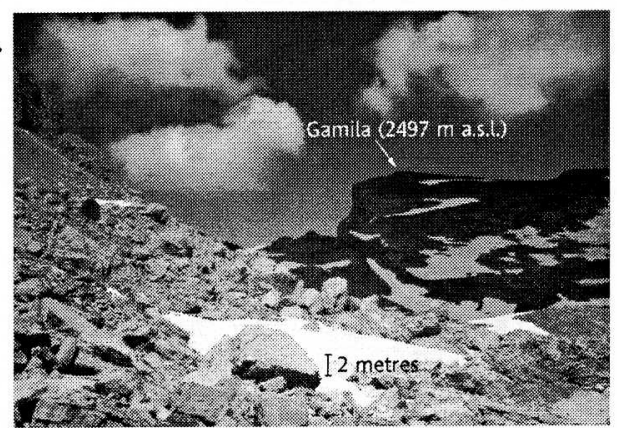

F.

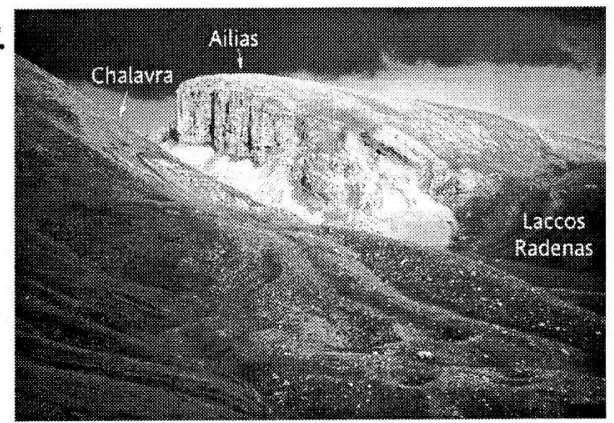

G.

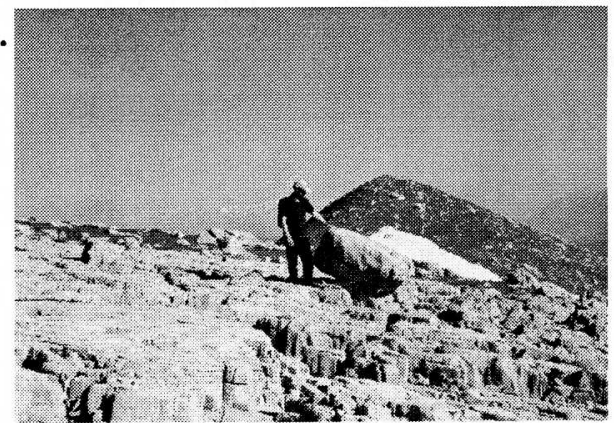

Figure 3. A, Poorly sorted gravels associated with glacier meltout (see Hughes et al., forthcoming $a$ ) of the Kato Radza member (unit Bla), containing vadose zone secondary carbonate (calcite; ca. lat $39^{\circ} 55^{\prime} 58 \mathrm{~N}$, long $20^{\circ} 52^{\prime} 09 \mathrm{E}$; $1773 \mathrm{~m}$ a.s.1.). B, A buried soil formed on glacial deposits of the Voidomatis member (unit A1) in the Tsepelovo Formation. The soil is truncated and buried by angular gravels that are interpreted as colluvium. This soil is a characteristic feature on the most extensive glacial stratigraphical units on Mount Tymphi. $C$, Moraines of the Vourtapa member in the Skamnelli Formation (unit B2a). These deposits represent the type area for the Vlasian Stage (MIS 6). D, Xeroloutsa, an ephemeral lake north of the peak Astraka. The lake is dammed by impressive boulder moraines of the Xeroloutsa member (unit J2). E, Large angular boulder deposits representing the Ploskos member (unit J3b) on the southeastern slopes of Ploskos. F, Moraines of the Laccos Radenas member (unit K1). G, A perched boulder on limestone pavement inside the moraines of the Stani Grava member (unit P2). 


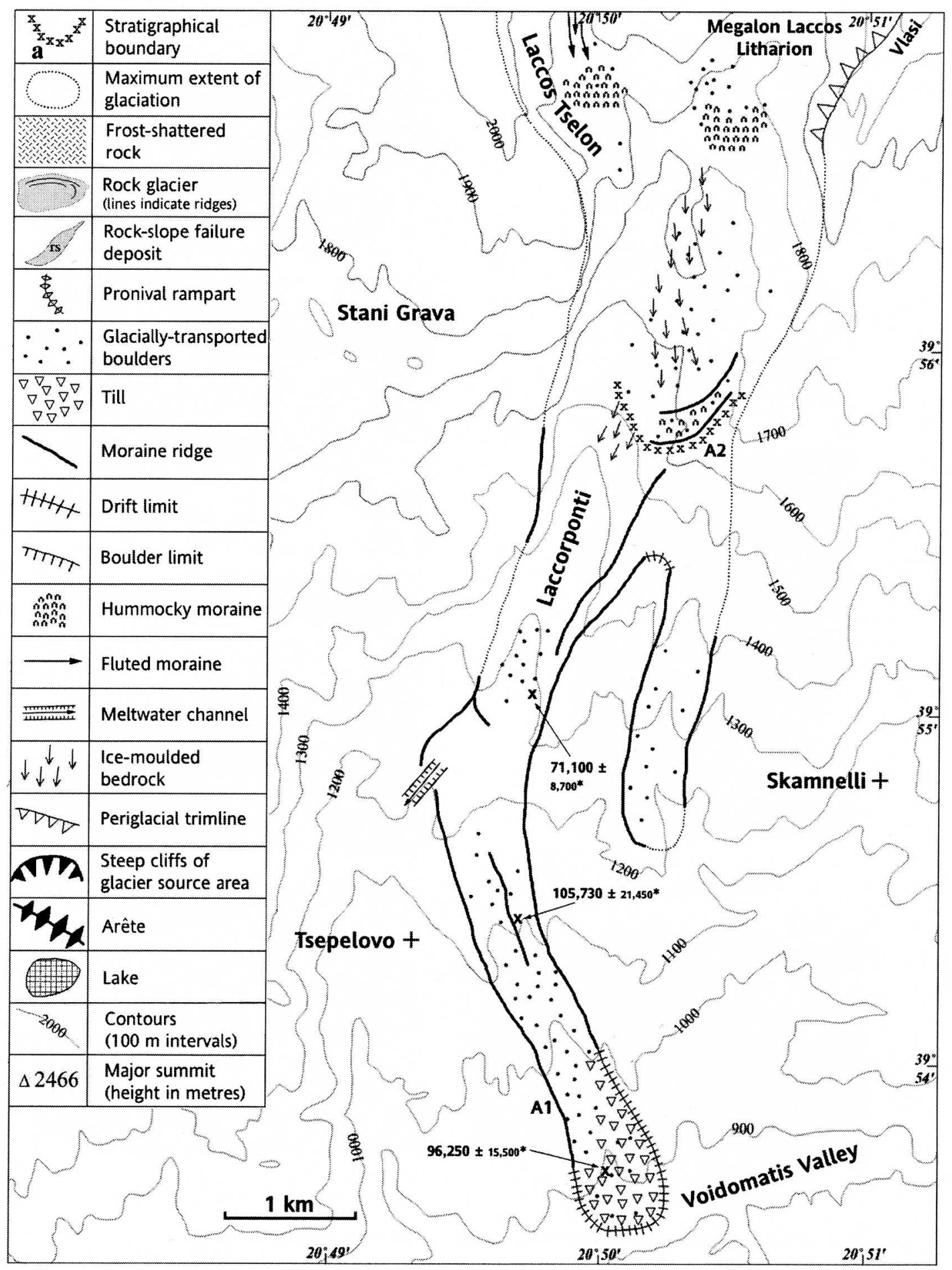

Figure 4. Glacial geomorphological map of the Tsepelovo Formation. Stratigraphical units are denoted $A 1$, Voidomatis member, and $A 2$, Laccorponti member. Where overlapping occurs with neighboring maps, geomorphological symbols are presented only in the map that presents the fullest glacial succession. The same rule applies for all maps. The locations and U-series ages of secondary carbonate samples are indicated. Where dates are $>350,000$ yr B.P., the sample code used in table A1 is indicated to aid differentiation between samples. Ages marked with an asterisk are from Woodward et al. (2004). 


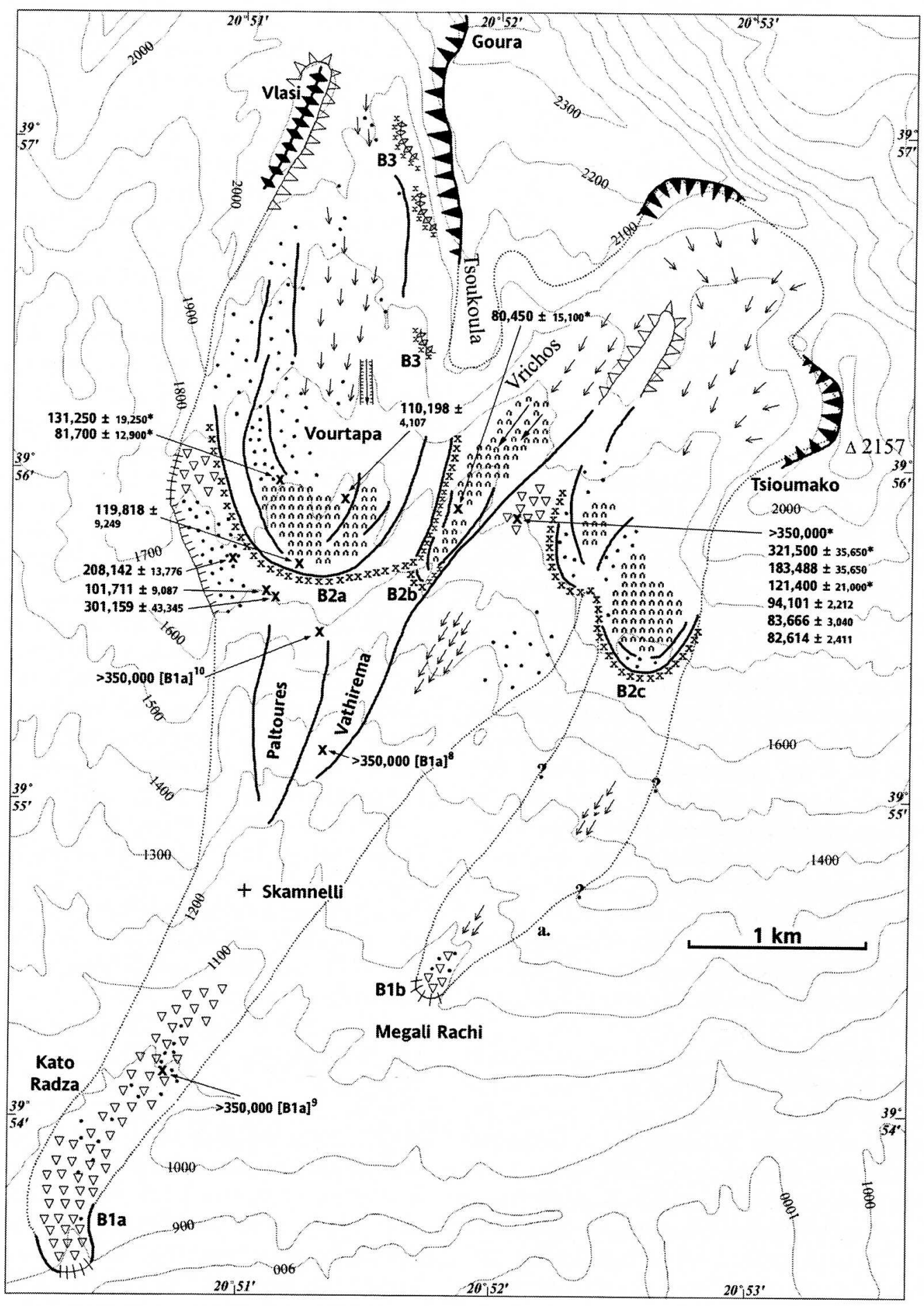

Figure 5. Glacial and periglacial geomorphological map of the Skamnelli Formation. Stratigraphical units are denoted B1a, Kato Radza member; B1b, Megali Rachi member; B2a, Vourtapa member; $B 2 b$, Vrichos member; B2c, Tsioumako member; and $B 3$, Tsoukoula member. 


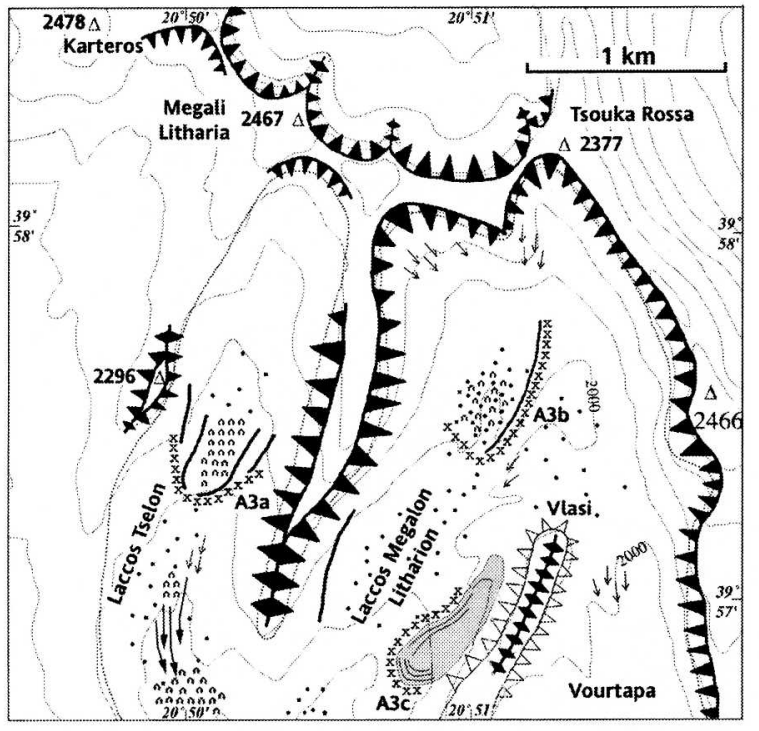

Figure 6. Glacial geomorphological map of the glacier source areas of the Tsepelovo and Skamnelli formations. Stratigraphical units are denoted $A 3 a$, Tselon member; $A 3 b$, Litharion member; and $A 3 c$, Vlasi member. These deposits represent part of the Tsepelovo Formation, while deposits to the east of the peak Vlasi are contiguous with the Vourtapa member of the Skamnelli Formation.

arion members; A3a, A3b). In addition, a prominent boulder lobe, identified by Hughes et al. (2003) as a relict talus rock glacier, occurs on the western slopes of Vlasi (Vlasi member; A3c). Small and slightly arcuate boulder ridges also exist close to the steep slopes of the Tsoukoula ridge in the Vourtapa valley (Tsoukoula member; B3; fig. 5). These are interpreted as pronival ramparts. In addition to geomorphological position, the moraines at the highest elevations can be clearly differentiated from those at midvalley elevations on the basis of soil profile weathering, and these data are discussed below.

Iliochori and Vrisochori Formations. Diamicts and gravels extend down to ca. $800-1000 \mathrm{~m}$ a.s.l. in the Maghoula and Kriopotamos valleys on the northeastern slopes of Mount Tymphi (fig. 7; Kriopotamos and Vrisochori members; C1, D1). In both valleys, the deposits form linear ridges close to valley sides and are interpreted as marginal moraines and subglacial deposits formed by former valley glaciers. As with the lowest and most extensive glacial deposits near Tsepelovo and Skamnelli, deep red soils are formed on their surfaces.

Higher in the valley, at ca. $1300-1500$ m a.s.l., moraines have formed at the lips of the Dimitrios, Laccos, and Plaghia tributary cirques of the Krio- potamos valley, and at the head of the Maghoula valley, below the peak of Goura (2466 m a.s.l.; Plaghia, Laccos, Tsouknidnes, and Maghoula members; C2a, C2b, C2c, D2). These wide moraines are distinct have a more subdued local relief and are composed of matrix-supported sediments in contrast to the higher ridges described below.

The highest deposits occur $<200 \mathrm{~m}$ from the break of slope at cirque backwalls (Eptapirghi, Dimitrios, and Portes members; C3a, C3b, D3). The deposits are composed of angular to subangular boulders and form sharp, slightly arcuate ridges. Dynamic ice is unlikely to have formed in the very limited space between these ridges and the backwall, and thus, the boulder ridges are interpreted as pronival ramparts, which formed in front of a perennial snowfield (cf. Shakesby 1997).

Neraidhovrisi, Aghia Triada, Mighia, and Amarandos Formations. The valleys on the northern slopes of Mount Tymphi (fig. 8) are the steepest in the study area. This has inhibited the preservation of glacial depositional landforms in some lower valley areas. In the Neraidhrovrisi area, diamicts are exposed in track and stream cuttings and contain large subrounded and striated boulders (Neraidhrovrisi member; E1). These deposits are interpreted as glacial in origin. However, the down-valley limit of these deposits is difficult to trace, as are upper valley deposits and landforms, because of thick forest cover and very steep terrain, especially in the upper areas. Since only one glacial unit has been recognized, these deposits represent the Neraidhovrisi Formation (fig. 9).

Further east in the Aghia Triada valley, evidence for glaciation is revealed in exposures of matrixsupported diamicts containing large subrounded boulders and perched surface boulders. However, to the west in the Mighia and Amarandos valleys (fig. 8), clearly defined boulder-covered moraines occur at ca. $1300 \mathrm{~m}$ a.s.l. On all of these lowermost glacial deposits (Aghia Triada, Mighia, and Drochaio members; F1, G1, H1), deep red soils have developed.

Arcuate midvalley moraines occur at ca. $1800 \mathrm{~m}$ a.s.l., in the Mighia valley at the threshold of a major riegel at the entrance to the Kopanes cirques, and at ca. $1600 \mathrm{~m}$ a.s.l., in the Amarandos valley (Limeria Klefton and Stomio members; G2, H2). Similarly positioned moraines also occur at ca. $1690 \mathrm{~m}$ a.s.l. at Stani Katsanou in the Aghia Triada valley (Stani Katsanou member; F2).

The highest deposits occur in the Tsouka Rossa, Karteros, Kopanes, Gamila, and Amarandos cirques (Tsouka Rossa, Karteros, Kopanes, Gamila, and Amarandos members; F3a, F3b, G3a, G3b, H3). 


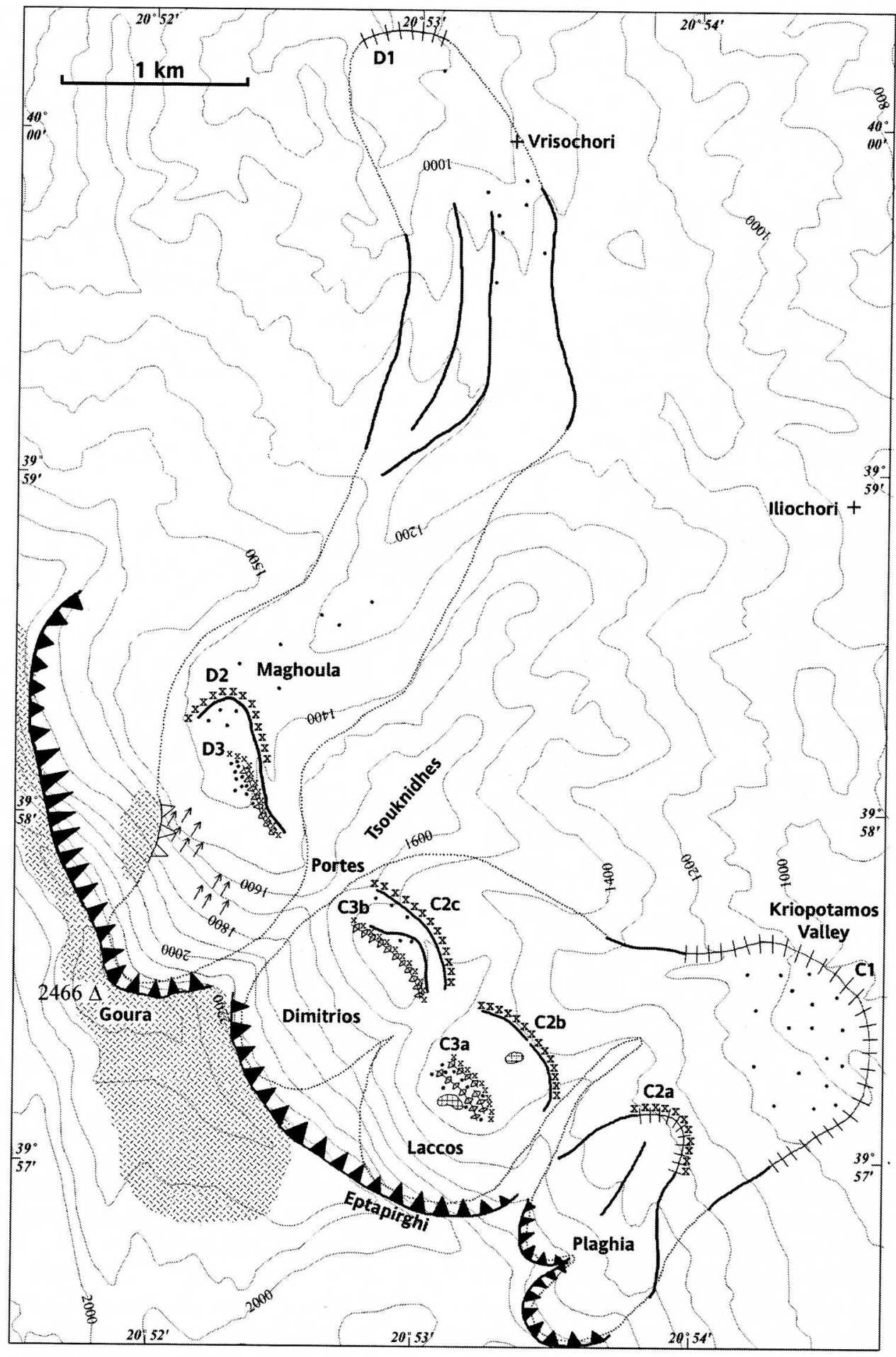

Figure 7. Glacial geomorphological map of the Iliochori and Vrisochori areas. Stratigraphical units are denoted C1, Kriopotamos member; C2a, Plaghia member; C2b, Laccos member; C2c, Tsouknidhes member; C3a, Epta Pirghi member; $C 3 b$, Dimitrios member; D1, Vrisochori member; D2, Maghoula member; and D3, Portes member. Units $C 1-C 3$ represent the Iliochori Formation, and units D1-D3 represent the Vrisochori Formation. 


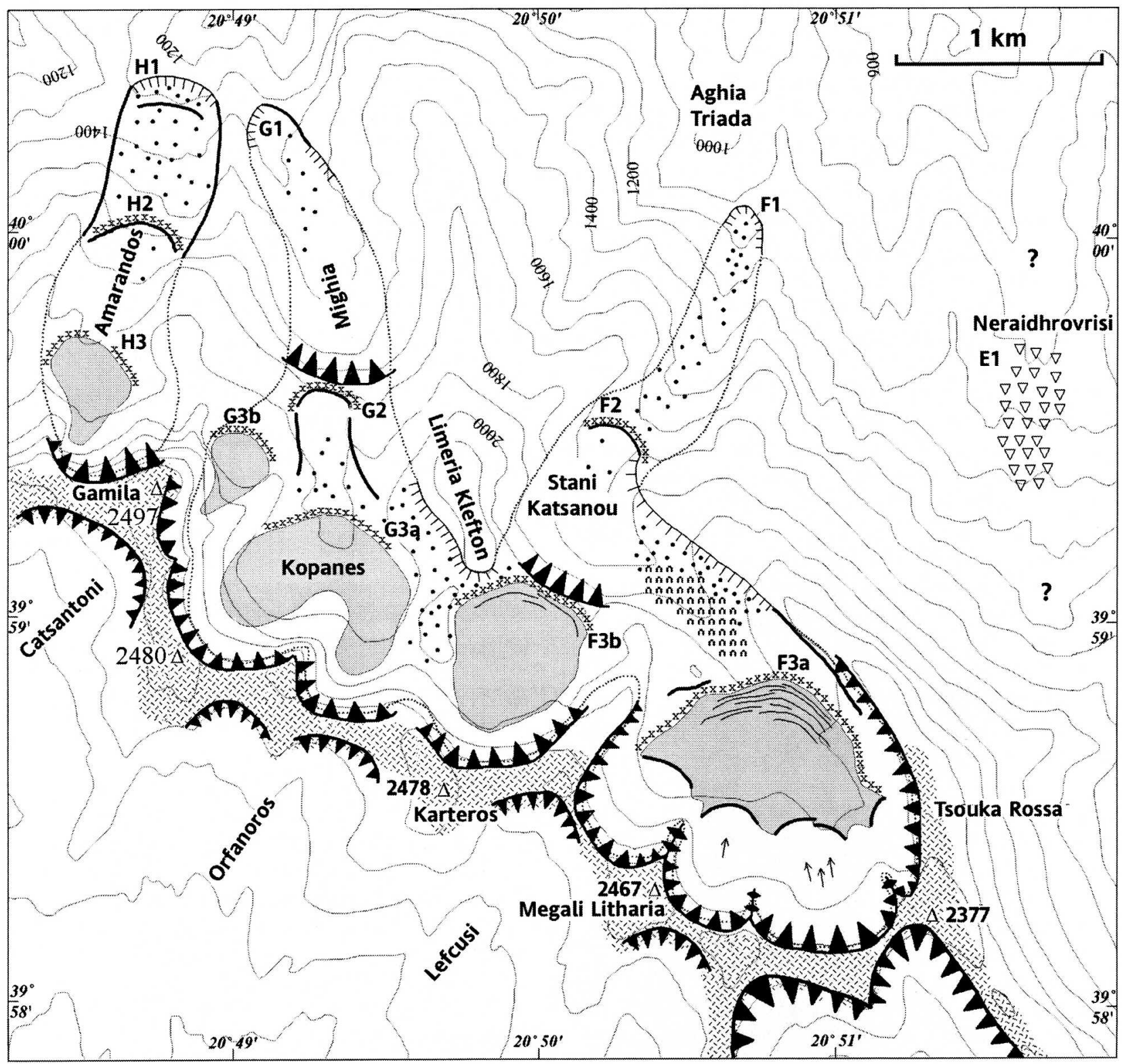

Figure 8. Glacial geomorphological map of the northern Tymphi area. Stratigraphical units are denoted E1, Neraidhovrisi member; F1, Aghia Triada member; F2, Stani Katsanou member; F3a, Tsouka Rossa member; F3b, Karteros member; G1, Mighia member; G2, Limeria Klefton member; G3a, Kopanes member; G3b, Gamila member; H1, Drochaio member; $H 2$, Stomio member; and $H 3$, Amarandos member. Unit $E 1$ represents the Neraidhovrisi Formation, units F1-F3 represent the Stani Katsanou Formation, units G1-G3 represent the Mighia Formation, and units H1H3 represent the Amarandos Formation.

These cirques are choked with boulders that form ridged lobate features above $1800 \mathrm{~m}$ a.s.l. The latter are interpreted as debris and talus rock glaciers, which formed as a result of permafrost creep and were supplied with debris from cirque moraines and talus, respectively (Hughes et al. 2003).

Astraka (Raidhovoli, Laccos Radenas, Spirokapa, and Ghaidhouro Formations). Diamicts containing stri- ated and subrounded clasts, boulder-covered ridges, and perched subrounded boulders provide abundant evidence of glaciation on the northern and southern slopes of the peak of Astraka (2436 m a.s.l.; figs. $10,11)$. On the northern slopes, in the Raidhovoli valley, diamicts similar to glacial sediments found elsewhere on Mount Tymphi are exposed in the steep northern part of the valley down to ca. 1500 


\begin{tabular}{|c|c|c|c|c|c|c|c|}
\hline & $\begin{array}{l}\text { Tsepelovo } \\
\text { Formation }\end{array}$ & $\begin{array}{l}\text { Skamnelli } \\
\text { Formation }\end{array}$ & $\begin{array}{l}\text { Iliochori } \\
\text { Formation }\end{array}$ & $\begin{array}{l}\text { Vrisochori } \\
\text { Formation }\end{array}$ & $\begin{array}{l}\text { Neraidhovrisi } \\
\text { Formation }\end{array}$ & $\begin{array}{l}\text { Stani Katsanou } \\
\text { Formation }\end{array}$ & $\begin{array}{c}\text { Mighia } \\
\text { Formation }\end{array}$ \\
\hline 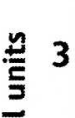 & $\begin{array}{l}\text { Soil PDI }=7.8 \\
\text { Tselon Member A3a } \\
\text { Litharion Member A3b } \\
\text { Vlasi Member A3C } \\
\end{array}$ & $\begin{array}{l}\text { Soil } \mathrm{PDI}=\mathbf{8 . 4} \\
\text { Tsoukoula Member } \mathbf{8 3}\end{array}$ & \begin{tabular}{|l|} 
Eptapirghi Member C3a \\
Dimitrios Member C3b
\end{tabular} & $\begin{array}{l}\text { Soil PDI }=9.0 \\
\text { Portes Member D3 }\end{array}$ & - & $\begin{array}{l}\text { Tsouka Rossa Mem. F3a } \\
\text { Karteros Member F3b } \\
\end{array}$ & $\begin{array}{l}\text { Kopanes Member G3a } \\
\text { Gamila Member G3b }\end{array}$ \\
\hline$\frac{\frac{\pi}{2}}{\frac{2}{0}} 2$ & $\begin{array}{l}\text { Soil PDI }=29.8 \\
\text { Laccorponti Mem. A2 }\end{array}$ & $\begin{array}{l}\text { Soil PDI }=30.4 \\
\text { Vourtapa Member B2a } \\
\text { Vrichos Member B2b } \\
\text { Tsioumako Member B2C }\end{array}$ & \begin{tabular}{|l|} 
Plaghia Member C2a \\
Laccos Member C2b \\
Tsouknidhes Mem. C2c \\
\end{tabular} & $\begin{array}{l}\text { Soil PDI }=38.3 \\
\text { Maghoula Member D2 }\end{array}$ & - & Stani Katsanou Mem. F2 & $\begin{array}{l}\text { Limeria Klefton } \\
\text { Member G2 }\end{array}$ \\
\hline 究 1 & $\begin{array}{l}\text { Soil PDI }=54.6 \\
\text { Voidomatis Mem. A1* }\end{array}$ & $\begin{array}{l}\text { Soil PDI }=51.8 \\
\text { Kato Radza Mem. B1a* } \\
\text { Megali Rachi Mem. B1b }\end{array}$ & Kriopotamos Mem. C1 & $\begin{array}{l}\text { Soil PDI }=61.0 \\
\text { Vrisochori Member D1 }\end{array}$ & Neraidhovrisi Mem. E1+ & Aghia Triada Mem. F1 & Mighia Member G1 \\
\hline & $\begin{array}{c}\text { Amarandos } \\
\text { Formation }\end{array}$ & $\begin{array}{l}\text { Raidhovoli } \\
\text { Formation }\end{array}$ & $\begin{array}{c}\text { Laccos Radenas } \\
\text { Formation }\end{array}$ & $\begin{array}{l}\text { Spirokapa } \\
\text { Formation }\end{array}$ & $\begin{array}{c}\text { Ghaidhouro } \\
\text { Formation }\end{array}$ & $\begin{array}{c}\text { Megas Laccos } \\
\text { Formation }\end{array}$ & $\begin{array}{c}\text { Stani Grava } \\
\text { Formation } \\
\end{array}$ \\
\hline$\frac{2}{2} 3$ & Amarandos Member $\mathrm{H} 3$ & $\begin{array}{l}\text { Astraka Member J3a } \\
\text { Ploskos Member 13b }\end{array}$ & - & - & - & - & - \\
\hline 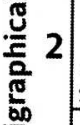 & Stomio Member $\mathbf{H} \mathbf{2}$ & Xeroloutsa Member J2* & - & - & - & Kazarma Member $\mathrm{N2}^{*}+$ & Stani Grava Mem. P2+ \\
\hline$\stackrel{\frac{2}{n}}{n} 1$ & Drochaio Member H1 & Raidhovoli Member J1 & Laccos Radenas K1*+ & Spirokapa Mem. LI+ & Ghaidhouro Mem. M1 + & $\begin{array}{l}\text { Megas Laccos } \\
+ \text { Member } \text { N1*+ }^{*}\end{array}$ & Dales member P1+ \\
\hline
\end{tabular}

Figure 9. Stratigraphical summary of the glacial and periglacial units on Mount Tymphi. This is based on a combination of morpho-lithostratigraphy and pedostratigraphy (Soil PDI = soil profile development index).

$\mathrm{m}$ a.s.l. The gentler upper valley area is bounded by moraines at ca. $1700 \mathrm{~m}$ a.s.l. that are contiguous with the latter deposits (Raidhovoli member; J1).

The ephemeral lake of Xeroloutsa below the Astraka refuge hut is contained by impressive bouldery moraines at ca. $1760 \mathrm{~m}$ a.s.l. (Xeroloutsa member J2; fig. 3D). These appear to have been formed by a glacier that emanated from beneath the shaded northern cliffs of Astraka, the former outline of which is defined by an extensive lateral moraine (fig. 10).

In contrast to the other areas of Mount Tymphi, there is no evidence for glacial deposits at higher elevations in the north Astraka area. However, at the base of the towering 500-m northern cliffs of Astraka peak itself, distinct boulder ridges are present (Astraka member; J3a). The ridges are ca. 10 $\mathrm{m}$ high on both sides of the crests and $<100 \mathrm{~m}$ from the base of the steep cliffs. They are composed of angular boulders and are likely to have formed at the base of perennial snowfields. In addition, extensive accumulations of exceptionally large boulders ( $>2 \mathrm{~m}$ in diameter) occur at the base of the eastern cliffs of Ploskos $(2377 \mathrm{~m}$ a.s.l.; Ploskos member; J3b; fig. $3 E$ ). It is probable that these sed- iments represent rock slope failure deposits and formed after glacier retreat from this area.

On the southern slopes of Astraka, moraines are present down to $1700 \mathrm{~m}$ a.s.l., at the edge of the Laccos Radenas gully, which drains into the Vikos Gorge (figs. 3F, 11; Laccos Radenas member; K1). Similar deposits and landforms also occur on the edges of the Vikos and Megas Laccos Gorges at Spirokapa (Spirokapa members; L1). Again, no higher deposits exist, and only one set of stratigraphically equivalent units was found in this area. On all moraines, surface soils are well developed and resemble the soils observed on the most extensive glacial deposits elsewhere on Mount Tymphi.

Megas Laccos and Stani Grava Formations. The whole of the upper catchment draining into the Megas Laccos Gorge displays evidence of glaciation (fig. 10). However, much of the evidence is erosional. For example, the Catsnatoni, Orfanoros, and Lefcusi cirques are cut into the southern slopes of the Tymphi ridge, and features such as limestone pavements and smooth elongate bedrock forms occur over wide areas. Occasional depositional features such as perched rocks are also present, but the main depositional evidence occurs in the upper 


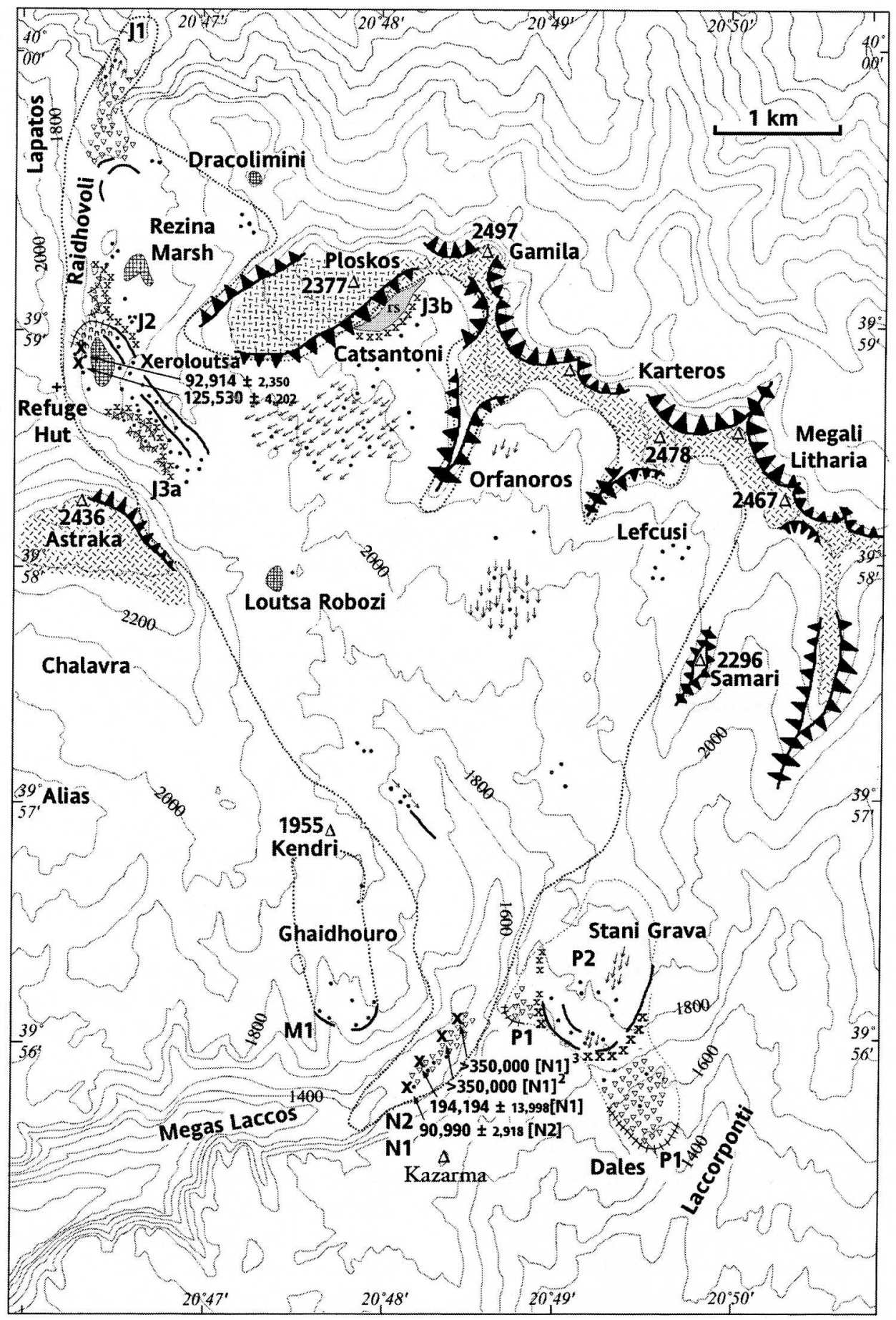

Figure 10. Glacial geomorphological map of the north Astraka area and upper catchment of the Megas Laccos. Stratigraphical units are denoted $J 1$, Raidhovoli member; $J 2$, Xeroloutsa member; $J 3 a$, Astraka member; J3b, Ploskos member; M1, Ghaidhouro member; N1, Megas Laccos member; N2, Kazarma member; P1, Dales member; and P2, Stani Grava member. Units J1-J4 represent the Raidhovoli Formation, unit M1 represents the Ghaidhouro Formation, units N1-N2 represent the Megas Laccos Formation, and units P1-P2 represent the Stani Grava Formation. 


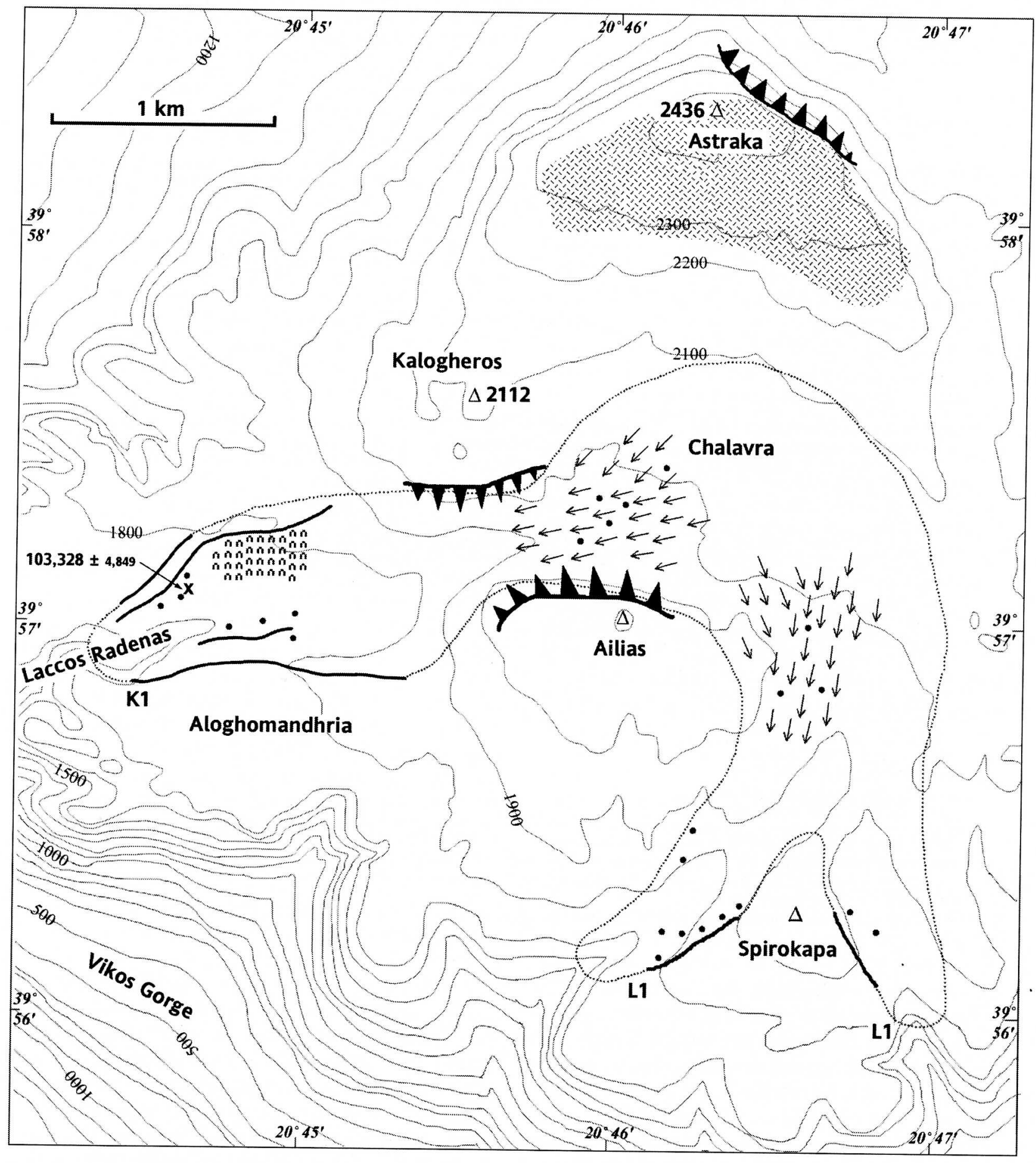

Figure 11. Glacial geomorphological map of the south Astraka area. Stratigraphical units are denoted $K 1$, Laccos Radenas member; and $L 1$, Spirokapa member. Unit $K 1$ represents the Laccos Radenas Formation, and $L 1$ represents
the Spirokapa Formation. 
Table 1. U-Series Dates from Secondary Carbonates (Calcite) within Glacial Stratigraphical Units on Mount Tymphi

\begin{tabular}{|c|c|c|c|c|}
\hline Unit & Dated units ${ }^{\mathrm{a}}$ & $\begin{array}{l}\text { Geomorphological } \\
\text { characteristics }\end{array}$ & Age of host glacial units & $\begin{array}{c}\text { Soil } \\
\text { characteristics } \\
\end{array}$ \\
\hline 3 & $\begin{array}{l}\text { No dates because of the absence of sec- } \\
\text { ondary carbonates. These deposits are } \\
\text { coarse grained and clast supported } \\
\text { and contain little or no matrix avail- } \\
\text { able for dissolution and } \\
\text { reprecipitation. }\end{array}$ & $\begin{array}{l}\text { Small cirque moraines } \\
\text { and relict rock gla- } \\
\text { ciers. Lowest eleva- } \\
\text { tion: }>1800 \mathrm{~m} \text { a.s.l. }\end{array}$ & $\begin{array}{l}\text { Geochronology undefined. How- } \\
\text { ever, the cirque moraines were } \\
\text { formed by the last glaciers in } \\
\text { Greece. Debris rock glaciers } \\
\text { were sourced from these cirque } \\
\text { moraines; and talus rock glaciers } \\
\text { formed in cirques after glacier } \\
\text { retreat. These deposits are corre- } \\
\text { lated with the last glacial cycle } \\
\text { and MIS 5d-2 (Weichselian/ } \\
\text { Würmian). }\end{array}$ & $\mathrm{PDI}=7.8-9.0$ \\
\hline 2 & $\begin{array}{l}\text { Vourtapa member (B2a): } \\
131,250 \pm 19,250 *(\text { MIS } 5 \mathrm{e} / 6) \\
118,450(119,818 \pm 9,249 ; \text { MIS 5e) } \\
109,116(110,198 \pm 4,107 ; \text { MIS5e) } \\
81,700 \pm 12,900 * \text { (MIS 5a) } \\
\text { Vrichos member (B2b): } \\
\text { 80,450 } \pm 15,100 *(\text { MIS } 5 \mathrm{a}) \\
\text { Xeroloutsa member (J2): } \\
\text { 92,536 (92,914 } \pm 2,350 ; \text { MIS 5c) } \\
\text { 121,731 (125,530 } \pm 4,202 ; \text { MIS 5e) } \\
\text { Kazarma member (N2): } \\
\text { 90,863 (90,990 } \pm 2,918 ; \text { MIS 5c) } \\
\end{array}$ & $\begin{array}{l}\text { Well-defined arcuate } \\
\text { moraines in midval- } \\
\text { ley positions. Low- } \\
\text { est elevation: ca. } \\
1500 \text { m a.s.l. Note: } \\
\text { the Kazarma mem- } \\
\text { ber is interpreted as } \\
\text { a periglacial unit. }\end{array}$ & $\begin{array}{l}\text { The oldest secondary carbonates } \\
\text { correlate with MIS 5e. One date } \\
\text { from Woodward et al. (2004) } \\
\text { overlaps MIS 5e and MIS 6. Sub- } \\
\text { sequent calcite generations date } \\
\text { from interstadials during MIS 5c } \\
\text { and 5a. The glacial units are cor- } \\
\text { related with MIS } 6 \text { (later } \\
\text { Saalian). }\end{array}$ & $\begin{array}{l}\mathrm{PDI}= \\
29.8-38.3\end{array}$ \\
\hline 1 & 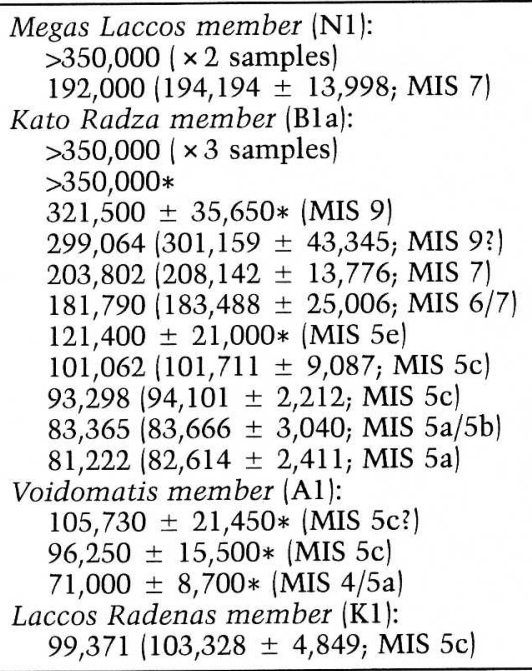 & $\begin{array}{l}\text { Poorly defined, but } \\
\text { extensive, moraines } \\
\text { in lower valley po- } \\
\text { sitions. Weathered } \\
\text { tills with thick and } \\
\text { well-developed } \\
\text { soils. Lowest eleva- } \\
\text { tion: ca. } 850 \mathrm{~m} \\
\text { a.s.l. }\end{array}$ & $\begin{array}{l}\text { The oldest secondary carbonates } \\
\text { are beyond the range of U-series } \\
\text { dating (>350,000 yr). This strati- } \\
\text { graphical unit also contains cal- } \\
\text { cites with ages correlating with } \\
\text { MIS } 9,7,5 \mathrm{e}, 5 \mathrm{c} \text {, and } 5 \mathrm{a} \text {. The } \\
\text { oldest secondary carbonates are } \\
\text { therefore correlated with MIS } \\
\text { 11. The glacial units are corre- } \\
\text { lated with MIS } 12 \text { (Elsterian). }\end{array}$ & $\begin{array}{l}\mathrm{PDI}= \\
\quad 51.8-61.0\end{array}$ \\
\hline
\end{tabular}

Note. Dates marked with an asterisk are from Woodward et al. (2004). The oldest secondary carbonate ages represent minimum ages for the host glacial deposits. Since secondary carbonates appear to have formed during interglacials or interstadials, the glacial deposits are likely to have formed during the cold stage immediately before the oldest phase of secondary carbonate formation. (Soil PDIs = soil profile development indexes.)

${ }^{a} \mathrm{U}$-series ages of secondary calcites $(\mathrm{yr})$. (MIS 5e) $=$ corresponding interval in the marine isotope record.

Megas Laccos Gorge itself and in shallow valleys to the west and east of the upper gorge.

To the north of the Megas Laccos Gorge, subrounded perched boulders and arcuate boulder ridges are present in the Ghaidhouro area (Ghaidhouro member; M1). These are interpreted as glacial in origin and appear to have formed by a small glacier occupying the shallow valley in this area and represent the sole unit of the Ghaidhouro Formation (fig. 9).

Within the Megas Laccos Gorge itself, diamicts containing subrounded and striated clasts are ex- posed at ca. $1500 \mathrm{~m}$ a.s.l. (Megas Laccos member; N1). These deposits are clearly of glacial origin and contrast markedly with nearby thick accumulations of angular and clast-supported breccias that are widespread in the gorge (Kazarma member; N2). The latter rest on top of the Megas Laccos member and may represent cold-stage colluvium formed by frost action during periods of enhanced periglacial activity (see tables 1 , in the text, and Al, available in the online edition or from the Journal of Geology office). The precise down-valley limit of glaciation is difficult to establish here because the glacial de- 
posits are fragmented and subject to removal by fluvial activity. However, until ca. 1400 m a.s.l., the upper Megas Laccos Gorge is broad based and U-shaped, while all lower areas are characteristically V-shaped. This marked transition in valley form probably represents the transition from glacial to fluvial regimes in the upper and lower gorge areas, respectively.

Above the gorge to the east, diamicts and perched boulders are present down to $1480 \mathrm{~m}$ a.s.l. in the area known as Dales (fig. 10). The diamicts contain subrounded and striated clasts, suggesting a glacial origin. These deposits represent the Dales member (P1). Up-valley, moraines are very well preserved (Stani Grava member; P2) with limestone pavements and perched subrounded boulders present within the shallow valley bounded by these moraines (fig. 3G). The area immediately in front of the moraines is characterized by a concentration of dolines. Waltham (1978) argued that these dolines have a genetic connection with the moraines, suggesting that they result from the action of meltwater at the front of the former glacier.

\section{Soil Analysis Results}

The morpho-lithostratigraphical succession of glacial units in each cirque-valley system represents the fundamental basis for a relative chronological framework. However, evidence from soil development data has been used to test this relative-age framework by providing a semiquantitative comparison of weathering horizons on the surface of glacial sediment units. This approach was particularly important in differentiating recessional and readvance moraines from the same phase of glaciation from moraines separated widely in time, such as those formed during different glacial cycles. The results are shown in figure 9 and table 1 and outlined below.

Soils on the oldest stratigraphical units were all at least $1 \mathrm{~m}$ thick, deep red in color (Munsell hue code [moist]: 2.5YR to 5YR), and of a strong medium subangular blocky structure. The soil aggregates were characterized by thick clay films in the B horizon. The characteristics of these soils produced Harden profile development indexes (PDIs) of between 51.8 and 61.0.

Higher midvalley moraines are clearly separated from the oldest glacial deposits and are much sharper and well preserved with thin surface soil profiles $(0.2-0.3 \mathrm{~m})-$ much thinner than on the lowermost moraines. The soils contain few clay fines and have a sandy texture with a weak subangular blocky structure. The soils were markedly less red in color (Munsell hue code [moist]: 7.5YR) than the soils on the lowermost stratigraphical glacial units and yielded PDIs of between 29.8 and 38.3.

The surfaces of the highest moraines, which formed in the uppermost cirques, are characterized by only very thin granular soils. Weathered soil profiles were not distinguishable on some coarsegrained bouldery moraines and were $<0.10 \mathrm{~m}$ thick where moraines contained a fine sediment matrix. These soils yielded PDIs of $<10$.

The differences in the PDIs derived for each stratigraphical glacial unit support the stratigraphical subdivision based on geomorphological grounds and also highlight significant contrasts in the relative age of the moraines on which the soils are formed. The fact that soil weathering would have been greatly enhanced under interglacial climates, compared with glacial climates, suggests that the glacial units are widely separated in time and not merely a product of different glacial events during a single last glacial cycle. Furthermore, the contrasting PDIs between glacial units are in accord with results from Mount Olympus in northeastern Greece presented by Smith et al. (1997), where soils on three stratigraphically separate glacial units yielded maximum PDIs of $81.7,38.0$, and 13.2 on the oldest to the most recent glacial units, respectively. While PDI values are rarely directly comparable between regions (Birkeland 1999), the fact that three sets of moraines on both Olympus and Tymphi yield markedly different PDIs supports the general model of three glaciations widely separated in time.

\section{Geochronology Results}

In total, 19 secondary carbonate samples taken from glacial units on Mount Tymphi were analyzed by U-series dating. All U-series ages and associated isotope ratios were obtained using TIMS, and their relationship to morpho-lithostratigraphical units is presented in tables $A 1$ and 1 . The dates for this study and the nine U-series dates presented in Woodward et al. (2004) provide a total of 28 dates for eight separate stratigraphical units in four cirque-valley systems.

X-ray diffraction showed that all of the secondary carbonates were calcite, and most of the calcite samples had ${ }^{230} \mathrm{Th} /{ }^{232} \mathrm{Th}$ ratios $>20$. Only three samples had ${ }^{230} \mathrm{Th} /{ }^{232} \mathrm{Th}$ ratios of $<20$ at ca. 11,13 , and 14. Detrital contamination is deemed significant when the ${ }^{230} \mathrm{Th} /{ }^{232} \mathrm{Th}$ activity ratio of a sample is $<20$ (Bischoff and Fitzpatrick 1991; Smart 1991). For consistency, all ages were corrected for the detrital 
contribution of $U$ and $T h$ to the samples. The mean ${ }^{232} \mathrm{Th} /{ }^{238} \mathrm{U}$ ratio of the detritus samples was 4.9 (range: 4.7-5.1). All the sites on Mount Tymphi are lithologically similar, and thus, the detrital contribution at all localities would be expected to be similar. The detrital contribution used in this study assumes that all ${ }^{232} \mathrm{Th}$ measured is of detrital origin, that the detritus is in secular equilibrium, and that the "clays" extracted to provide a $\mathrm{Th} / \mathrm{U}$ ratio for the calculation were representative of the likely detrital contamination for all samples.

The secondary carbonates often coated large clasts within diamicts or filled interclast voids and were usually localized deposits with little lateral extension (fig. $3 A$ ). Some of the calcites were up to $5 \mathrm{~cm}$ thick and consisted of multiple layers, and in places, small dripstones or stalactites had developed within voids in the sediment matrix. This type of secondary carbonate is interpreted as being formed by localized water flow through the unconsolidated sediments in the vadose zone, above the water table. Since these carbonates coat glacially transported clasts and boulders and fill interclast voids, it is clear that they postdate the host sediment.

The U-series results show that all of the ages and associated error margins coincide with interglacial or interstadial intervals or at least straddle their defined boundaries, with the exception of samples dated at $>350,000 \mathrm{yr}$, where the precise age is unknown (table 1). Several factors would have promoted vadose zone secondary calcite formation during interglacial or interstadial climates: (1) calcite precipitation is promoted by increasing water temperatures and evaporation rates because this augments the concentration of calcium and bicarbonate ions in the water, (2) a respiring surface soil causes carbon dioxide to be lost from calcium carbonate-rich waters and promotes calcite precipitation, and (3) increased moisture supply during interglacials would have provided a water supply for vadose zone percolation.

\section{A Chronostratigraphical Framework for Cold Stages in Greece}

Stratigraphical problems encountered when dealing with the fragmentary nature of mountain glacial records, especially with respect to chronostratigraphy, can be resolved by comparing local sequences to a continuous record nearby, which can provide a reference parasequence (Hughes et al. 2005). In this study, the continuous lacustrine sequence at Ioannina was used for this purpose (cf. Tzedakis 1994; Tzedakis et al. 2002). Tzedakis
(1994) showed that the long (ca. 423,000 yr) lacustrine pollen sequence at Ioannina can be correlated with the marine isotope record (cf. Ninkovich and Shackleton 1975; Shackleton and Pisias 1985). This is also the case for other long continuous lacustrine sequences in Greece, including Tenaghi Philippon (Wijmstra 1969; Wjimstra and Smit 1976; Wijmstra and Groenhart 1983; van der Wiel and Wijmstra $1987 a, 1987 b$ ) and several other terrestrial sequences in southern Europe (Tzedakis et al. 1997).

The Ioannina sequence has the advantage of being $<40 \mathrm{~km}$ from Mount Tymphi, on the western side of the main Pindus axis in northwest Greece (fig. 1). Tenaghi Philippon is $>300 \mathrm{~km}$ to the northeast of the field area and lies in the lee of the Pindus range. The sequence at Ioannina is therefore likely to reflect the climatic events in the local mountains more closely than the sequence at Tenaghi Philippon. Although Ioannina is adopted here as the formal primary parastratotype, both sequences are referred to in the following discussion. In fact, two parastratotypes are used, from the adjacent cores Ioannina 249 (Tzedakis 1994) and Ioannina 284 (Tzedakis et al. 2002).

The earliest cold stage is termed here the Skamnellian Stage after the village of Skamnelli near to where both the Kato Radza and Megali Rachi members are located. The type section for the Skamnellian Stage occurs in the deposits of the Kato Radza member (B1a) south of Skamnelli village at ca. lat $39^{\circ} 54^{\prime} 08 \mathrm{~N}$, long $20^{\circ} 50^{\prime} 40 \mathrm{E}, 984 \mathrm{~m}$ a.s.l. (fig. $5)$. The next stage is termed the Vlasian Stage, after the mountain of Vlasi (ca. $2200 \mathrm{~m}$ a.s.l.) that separates the Vourtapa and upper Laccorponti valleys (figs. 4, 5), where deposits of this stage are very well represented (fig. $3 \mathrm{C}$ ). The type locality for this stage is situated on the eastern side of Vlasi, in the Vourtapa valley, and characterized by deposits of the Vourtapa member (B2a), and the type section is situated at ca. lat $39^{\circ} 55^{\prime} 50 \mathrm{~N}$, long $20^{\circ} 51^{\prime} 10 \mathrm{E}, 1650 \mathrm{~m}$ a.s.l. The most recent stage on Mount Tymphi is named the Tymphian stage because most of the associated glacial and periglacial deposits are situated in cirques close to its central and highest ridge. The type locality is characterized by the deposits of the Tsouka Rossa member (F3a) at ca. lat $39^{\circ} 58^{\prime} 45 \mathrm{~N}$, long $20^{\circ} 50^{\prime} 40 \mathrm{E}, 2025 \mathrm{~m}$ a.s.l. (fig. 8). In all cases, the glacial and periglacial deposits representing the type sections and type areas rest on bedrock and are separated by an erosional boundary, hence the need for a reference parastratotype.

Minimum ages for the glacial sediments obtained by U-series dating and relative ages obtained by soil profile indexes assist the designation of chronostratigraphical boundaries relative to the Ioannina 
parasequence (fig. 12). The Skamnellian Stage clearly predates 350,000 yr B.P., with six separate secondary carbonate samples from two separate stratigraphical units yielding ages older than $350,000 \mathrm{yr}$ (table 1). In addition, many of the deposits are capped by well-developed soils demonstrating a prolonged period of weathering. At Ioannina, this stage must correspond to cold intervals before the Dodoni Interglacial, which has been correlated to MIS 11 (Tzedakis 1994; fig. 12). It is proposed that the calcites yielding ages older than 350,000 yr B.P. date from the Dodoni Interglacial (MIS 11) and that the Skamnellian Stage correlates with the cold interval that immediately precedes this interglacial, MIS 12 (Woodward et al. 2004). This interval corresponds with pollen zones IN $2 \mathrm{a}$ to IN 5, and accordingly, the base of the Skamnellian stage is at $184.00 \mathrm{~m}$ in the Ioannina 249 sequence. Arguments in favor of this proposal are discussed below with reference to another nearby pollen record and the glacial record in northern Europe.

At Tenaghi Philippon, the Dodoni Interglacial is locally termed the Lekanis Interglacial (van der Wiel and Wijmstra 1987b; Tzedakis et al. 1997). The preceding cold interval, between the Lekanis and Alistrati II interglacials, is thought to have spanned the period $445,000-400,000$ yr B.P. and is also correlated with MIS 12 (van der Wiel and Wijmstra 1987b). This is equivalent to the Elsterian Stage in northern Europe. The Elsterian Stage was characterized by the most extensive ice cover of the Middle-Late Pleistocene in northern and eastern Europe (Sibrava et al. 1986), and the interval equivalent to MIS 12 at Tenaghi Philippon was the most extreme interval recorded in the entire sequence, with some samples containing $0 \%$ arboreal pollen frequencies (Tzedakis et al. 2003). The preceding major "glacial" phase on the basis of the pollen stratigraphy occurred much earlier, between 621,000 and 562,000 yr B.P. in the interval between the Niki and Falakron interglacials, and is correlated with MIS 16 (van der Wiel and Wijmstra $1987 b$ ). If the Skamnellian deposits do belong to this glacial phase (or even earlier phases, such as between the Polistilos and Niki interglacials at Tenaghi Philippon, correlated with MIS 18 between 701,000 and $649,000 \mathrm{yr}$ B.P.), then this would imply remarkable and widespread preservation of very ancient glacial deposits. Given the nature of the geochronological method applied, where U-series ages of secondary calcites provide minimum ages, there will always be the possibility that the Skamnellian Stage deposits are older than the age defined here. However, the current balance of evidence favors

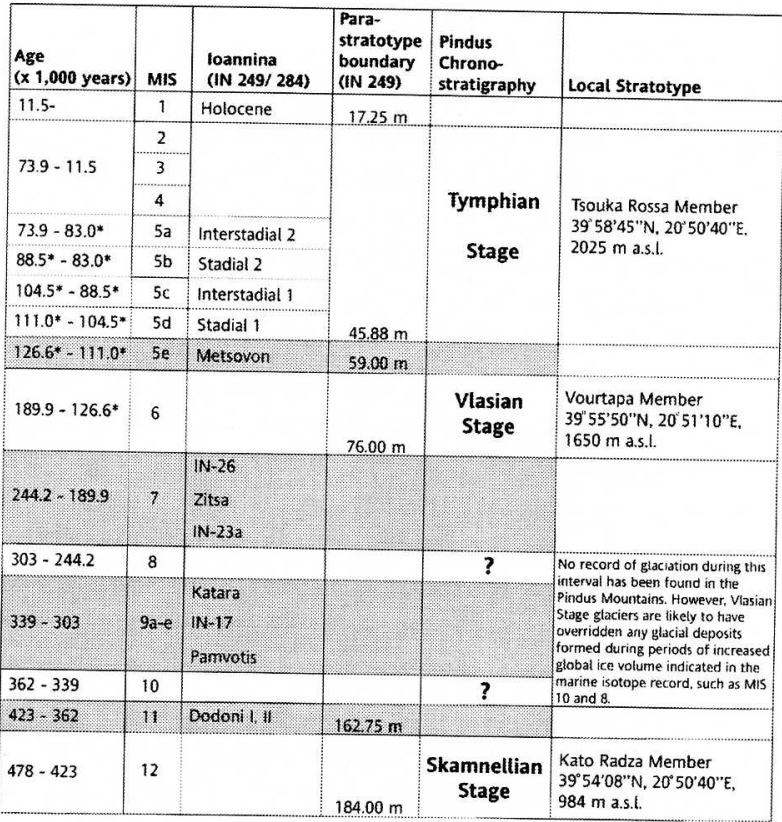

Figure 12. Chronostratigraphical table showing the relationship between the fragmentary glacial and periglacial sequence in the Pindus Mountains, Greece, and the continuous lacustrine parasequence in the nearby Ioannina 249 and 284 cores (cf. Tzedakis 1994; Tzedakis et al. 2002). $M I S=$ marine isotope stage. Asterisk = interval ages from Tzedakis et al. (2002); all other dates from orbitally tuned marine isotope records (Imbrie et al. 1984; Martinson et al. 1987).

correlating the Skamnellian Stage with the preDodoni cold phase at Ioannina.

The deposits of the Vlasian Stage predate the Metsovon Interglacial $(127,000-111,000$ yr B.P.; MIS $5 \mathrm{e}$ ) and postdate the Zitsa Interglacial and associated interstadials $(250,000-190,000$ yr B.P.; MIS 7). The oldest U-series date obtained from Vlasian Stage deposits was reported in Woodward et al. (2004) at 131,250 $\pm 19,250$ yr B.P. The oldest date obtained in the study presented here is 118,450 $(119,818 \pm 9,249)$ yr B.P., from deposits of the Vourtapa member of the Skamnelli Formation (table 1) - the same deposits dated using different secondary carbonate samples by Woodward et al. (2004). In addition, soils on Vlasian Stage deposits are much less well developed than soils on Skamnellian Stage deposits, suggesting a large difference in age. This fact, combined with the much younger U-series dates obtained from secondary carbonates within Vlasian Stage deposits, suggests a much younger age for the Vlasian Stage glacial units compared with those formed during the Skamnellian.

The absence of secondary carbonates older than 
$131,250 \pm 19,250$ yr B.P. in the Vlasian Stage deposits supports the correlation of these deposits with the "cold" stage immediately preceding the last interglacial interval in Greece. This can be defined as the interval between the base of the Metsovon interglacial (pollen zone IN 29; base, 59.00 $\mathrm{m})$ and the top of pollen zone IN $26(76.00 \mathrm{~m})$ in the Ioannina 249 sequence (cf. Tzedakis 1994). This interval is correlated with MIS 6 (Tzedakis 1994). It is unlikely that the Vlasian Stage glacial deposits formed during an earlier cold stage because no secondary carbonates within our sample of eight from this stratigraphical unit yielded older ages corresponding to earlier interglacials or interstadials. If glaciation did occur during intervals, such as MIS 8 or 10 , then the glaciers must have been less extensive than the later glaciers of the Vlasian Stage, and their deposits must have been removed and/or incorporated into the Vlasian Stage deposits.

While the span of the Vlasian Stage can be defined, the precise timing of the glacier maximum during the Vlasian Stage is difficult to establish, based on current evidence, although for the interval $133,000-129,300$ yr B.P., arboreal pollen percentages fall below $20 \%$ in the Ioannina 284 core (Tzedakis et al. 2002). However, the maximum extent of glaciers during the Vlasian Stage on Mount Tymphi may not necessarily have occurred at this time. The local glacier maximum may have occurred during an interval of cold yet more moist conditions when arboreal pollen frequencies were higher. However, high-resolution pollen data preceding 133,000 yr B.P. from the Ioannina 284 core are yet to be published.

The Tymphian Stage deposits are undated because of the absence of secondary calcite in these deposits. However, the Tymphian Stage deposits are clearly younger than those of the Vlasian Stage, based on stratigraphical position and soil PDI data. It is probable that they formed during the last glacial cycle, which is equivalent to the interval between the top of the Metsovon Interglacial $(45.88$ $\mathrm{m}$ ) and the base of the Holocene (17.25 m; Tzedakis 1994). This interval is comparable to the Würmian Stage, the only formally defined Alpine chronostratigraphical unit (Chaline and Jerz 1983, 1984), and the Weichselian Stage of northern Europe, respectively. Hughes et al. (2006a) identified at least 10 intervals when glaciers could have formed during the Tymphian Stage and emphasized the likelihood of glacier oscillation in response to millennial-scale climate change. On neighboring Mount Smolikas (2637 m a.s.l.), ca. $15 \mathrm{~km}$ to the northeast of Mount Tymphi, moraines occur at altitudes greater than the highest cirque floors on Mount
Tymphi and may represent glacier readvance during the Younger Dryas $\left(11,000-10,000{ }^{14} \mathrm{C}\right.$ yr B.P.; Hughes et al. 2006b).

\section{Comparison with Other Mediterranean Glacial Records}

The glacial sequence in the Pindus Mountains is comparable to that recorded on Mount Olympus to the east (Smith et al. 1997). In both areas, three major glacial units are recorded with evidence for a fourth readvance phase in the highest cirques. On Mount Olympus, Smith et al. (1997) proposed that glacial units formed during MIS 4-2, 6, and 8, based on correlations between dated soil chronosequences in a nearby alluvial basin. This corresponds well with the chronostratigraphical framework for Mount Tymphi, with MIS 4-2 and 6 correlating with parts of the Tymphian and Vlasian Stages, respectively. However, there is no evidence for glaciation during an interval equivalent to MIS 8 on Mount Tymphi, with the oldest deposits forming before 350,000 yr B.P.- during the Skamnellian Stage, which is equivalent to MIS 12. Given that the most extensive glacial deposits on Mount Olympus were not dated directly, it is possible that they formed earlier than MIS 8 and may also date from the Skamnellian Stage (MIS 12).

As far as the wider Mediterranean region is concerned, a recognized glacial phase equivalent to the Skamnellian Stage and MIS 12 is so far unique to Greece. No other glacial deposits in the Mediterranean have yielded such early ages. However, this is not to say that equivalent deposits do not exist. For example, in Italy, it has been suggested that glacial deposits predating Rissian Stage deposits occur on Mount Navert (Jaurand 1994). Also, in the Pyrenees, highly weathered tills extend beyond Rissian Stage glacial limits that Calvet (2004) has suggested might represent glaciation during the early Middle Pleistocene. A similar situation has been proposed for glacial landforms in northern Spain (Gale and Hoare 1997), although in all of these regions, in contrast to the Pindus Mountains of Greece, the geochronology has not been established.

Glacial deposits and landforms equivalent to the Vlasian Stage and MIS 6 have been recognized elsewhere in the Mediterranean, such as in the Pyrenees (Calvet 2004), North Africa (Hughes et al. 2004), and Turkey (Ciner 2004), although again, most deposits remain undated. However, equivalent glacial deposits and landforms have been dated in Italy and Iberia. For example, in the Gran Sasso, Italy, Kotarba et al. (2001) have dated secondary 
carbonates within glacial deposits using a U-series, and they demonstrated that the host glacial deposits formed before the last interglacial, probably during the Rissian Stage. In northwest Iberia, Fernandez Mosquera et al. (2000) applied cosmogenic dating to glacially polished surfaces and pushmoraine boulders of three separate glacial phases. The oldest glaciation was dated to before ca. 238,000 yr B.P., the intermediate phase to ca. 130,000 yr B.P., and the youngest to ca. $15,000 \mathrm{yr}$ B.P. In common with the glacial record in Greece, three major glaciations have been identified, although the oldest glacial phase is younger than that recorded in Greece and may correspond to a glaciation during the early Rissian (ca. MIS 8).

The glacial record on the southern slopes of Mount Tymphi can usefully be compared with the fluvial sedimentary record in the Voidomatis River basin downstream. A series of terraced alluvial units in the lower Vikos gorge and Konitsa basin contain significant quantities of sediment derived from the glaciated upper catchment (Bailey et al. 1990; Lewin et al. 1991; Woodward et al. 1992; Hamlin et al. 2000). The presence of silt-rich, finegrained, limestone-derived matrix is a distinctive feature of these units, and this material is derived from crushing and abrasion in a glacial environment (Woodward et al. 1992). Hamlin et al. (2000) recognized at least four separate alluvial units containing secondary carbonates yielding maximum U-series ages of ca. 113,000, 78,000, 55,000, and 25,000 yr B.P. in each unit (these secondary carbonates appear to have been related to the phreatic zone, and it is possible that these formed under very different climatic conditions to vadose zone types found in glacial deposits). These ages fall within the Tymphian Stage, for which only one stratigraphical unit is recorded in the glacial and periglacial record upstream. It is possible that the fluvial sequence records response to multiple episodes of glacier activity during the Tymphian Stage, with only the last of these being recorded in the glacial stratigraphical record (cf. Hughes et al. 2006a). Earlier glaciations during the Vlasian and Skamnellian Stages were much more extensive than the Tymphian Stage glaciation, and glacial erosion is likely to have contributed significant amounts of sediment to the Voidomatis River. This would have been the case throughout the Pindus Mountains, and the large Middle Pleistocene glaciations would have been major periods of landscape change and sediment transfer.

\section{Conclusions}

The glacial and periglacial sequence in the northern Pindus Mountains represents the most complete sequence of its kind so far recognized in the Mediterranean, and it is the best-dated glacial sequence in this region. Similar records are likely to exist elsewhere, although little progress has been made to establish the geochronology of other Mediterranean glacial successions. The establishment of a formal stratigraphical framework in conjunction with a nearby reference pollen parasequence has enabled, for the first time, the development of a Middle and Late Pleistocene chronostratigraphy for Greece. The oldest recorded glacial deposits formed during the Middle Pleistocene. The oldest glacial chronostratigraphical unit in the Pindus Mountains is termed the Skamnellian Stage, which correlates with the Elsterian Stage of northern Europe and MIS 12. A further Middle Pleistocene glaciation occurred during the Vlasian Stage, representing an interval equivalent to the part of the Saalian Complex in northern Europe and MIS 6. The most recent glacial deposits formed during the Tymphian Stage, which correlates with the last glacial stage recorded elsewhere, such as the Weichselian/Würmian Stages of northern Europe and the Alps and MIS $5 \mathrm{~d}-2$.

\section{A C K N O WLEDGMENTS}

P. D. Hughes was funded by a University of Cambridge Domestic Research Studentship and fieldwork grants from Darwin College, Cambridge European Trust; Quaternary Research Association; British Geomorphological Research Group; and the Cambridge Philosophical Society. The U-series dating program was undertaken at the U-series Facility at the Open University, Milton Keynes, United Kingdom, supported by the Natural Environment Research Council (NERC; reference no. IP/754/ 0302 ) to P. D. Hughes, P. L. Gibbard, and J. C. Woodward. We would like to thank J. Rhodes for processing some of the samples. U-series dating was also supported by a NERC grant (GR9/2916) to M. G. Macklin and J. C. Woodward. All fieldwork was undertaken with permission and support of the Institute of Geological and Mineral Exploration of Greece. We would like to thank C. Tzedakis and $\mathrm{K}$. Roucoux (University of Leeds) for comments on the chronostratigraphical model proposed in this article and also G. Mastronuzzi (University of Bari) and G. Thackray (Idaho State University) for very helpful comments on earlier drafts of this article. 


\section{R E F E R E N C E S C I T E D}

Alimen, H. 1964. Le Quaternaire des Pyrénées de la Bigorre. Mémoires du Service de la Carte Geologique de France, Paris. 286p.

Bailey, G. N.; Lewin, J.; Macklin, M. G.; and Woodward, J. C. 1990. The "older fill" of the Voidomatis valley, north-west Greece and its relationship to the Palaeolithic archaeology and glacial history of the region. J. Archaeol. Sci. 17:145-150.

Bailey, G. N.; Turner, C.; Woodward, J. C.; Macklin, M. G.; and Lewin, J. 1997. The Voidomatis basin: an introduction. In Bailey, G. N., ed. Klithi: Palaeolithic settlement and Quaternary landscapes in northwest Greece. Vol. 2. Klithi in its local and regional setting. Cambridge, McDonald Institute for Archaeological Research. p. 321-345.

Barrère, P. 1963. La période glaciaire dans l'ouest des Pyrénées centrales franco-espagnoles. Bull. Soc. Geol. Fr. 7:516-526.

Birkeland, P. W. 1999. Soils and geomorphology. 3rd ed. Oxford, Oxford University Press.

Bischoff, J. L, and Fitzpatrick, J. A. 1991. U-series dating of impure carbonates: an evaluation of the isochron technique using total sample dissolution. Geochim. Cosmochim. Acta 55:543-554.

Boenzi, F., and Palmentola, G. 1997. Glacial features and snow-line trend during the last glacial age in the southern Apennines (Italy) and on Albanian and Greek mountains. Z. Geomorphol. 41:21-29.

Boenzi, F.; Palmentola, G.; Sanso, P.; and Tromba, F. 1992. Le tracce glaciali del Massiccio dello Smolikas (Catena Del Pindo-Grecia). Riv. Geogr. Ital. 99:379-393.

Bögli, A. 1964. Un exemple de complexe glacio-karstique: le schichtreppenkarst. Rev. Belge Geogr. 88:63.

1980. Karst hydrology and physical speleology. Berlin, Springer. 284 p.

Calvet, M. 2004. The Quaternary glaciation of the Pyrenees. In Ehlers, J., and Gibbard, P. L., eds. Quaternary glaciations: extent and chronology. Pt. I. Europe. Amsterdam, Elsevier. p. 119-128.

Chaline, J., and Jerz, H. 1983. Proposition de création d'un étage würmien par la sous-Commission de Stratigraphie du Quaternaire Européen de l'INQUA. Bull. Assoc. Fr. Etud. Quaternaire 16:149-152.

. 1984. Arbeitsergebnisse der Subkommission für Europäische Quartärstratigraphie: stratotypen des Würm-Glazials (Berichte der SEQS 6). Eiszeitalter und Gegenwart 35:185-206.

Ciner, A. 2004. Turkish glaciers and glacial deposits. In Ehlers, J., and Gibbard, P. L., eds. Quaternary glaciations: extent and chronology. Pt. I. Europe. Amsterdam, Elsevier. p. 419-429.

Edwards, R. L.; Chen, H.; and Wasserburg, G. J. 1987. ${ }^{238} \mathrm{U}_{-}{ }^{234} \mathrm{U}-{ }^{230} \mathrm{Th}-{ }^{232} \mathrm{Th}$ systematics and the precise measurement of time over the past 500,000 years. Earth Planet. Sci. Lett. 81:175-192.

Fairchild, I. J.; Bradby, L.; and Spiro, B. 1994. Reactive carbonate in glacial systems: a preliminary synthesis of its creation, dissolution and reincarnation. In Deynoux, M.; Miller, J. M. G.; Domack, E. W.; Eyles, N.; Fairchild, I. J.; and Young, G. M., eds. Earth's glacial record. International Geological Correlation Project 260. Cambridge, Cambridge University Press, p. 176192.

Federici, P. R. 1980. On the Riss glaciation of the Apennines. Z. Geomorphol. 24:111-116.

Fernandez Mosquera, D.; Marti, K.; Vidal Romani, J. R.; and Weigel, A. 2000. Late Pleistocene deglaciation chronology in the NW of the Iberian Peninsula using cosmic-ray produced $21 \mathrm{Ne}$ in quartz. Nucl. Instrum. Methods Phys. Res. B 172:832-837.

Gale, S. J., and Hoare, P. G. 1997. The glacial history of the northwest Picos de Europa of northern Spain. Z. Geomorphol. NF 41:81-96.

Hamlin, R. H. B.; Woodward, J. C.; Black, S.; and Macklin, M. G. 2000. Sediment fingerprinting as a tool for interpreting long-term river activity: the Voidomatis basin, northwest Greece. In Foster, I. D. L., ed. Tracers in geomorphology. Chichester, Wiley, p. 473-501.

Harden, J. W. 1982. A quantitative index of soil development from field descriptions: examples from a chronosequence in central California. Geoderma 28: 1-28.

Hughes, P. D.; Gibbard, P. L.; and Woodward, J. C. 2003. Relict rock glaciers as indicators of Mediterranean palaeoclimate during the Last Glacial Maximum (Late Würmian) of northwest Greece. J. Quat. Sci. 18:431440.

. 2004. Quaternary glaciation in the Atlas Mountains, North Africa. In Ehlers, J., and Gibbard, P. L., eds. Quaternary glaciation: extent and chronology. Vol. 3. Asia, Latin America, Africa, Australia, Antarctica. Amsterdam, Elsevier, p. 255-260.

. 2005. Quaternary glacial records in mountain regions: a formal stratigraphical approach. Episodes 28:85-92.

Hughes, P. D.; Woodward, J. C.; and Gibbard, P. L. $2006 a$. Late Pleistocene glaciers and climate in the Mediterranean. Global Planet. Change 50:83-98.

. 2006b. The last glaciers of Greece. Z. Geomorphol. 50:37-61.

. Forthcoming $a$. Middle Pleistocene glacier-sediment dynamics in the Mediterranean: sedimentological evidence from the Pindus Mountains, Greece. J. Geol. Soc. Lond.

. Forthcoming $b$. Quaternary glacial record of the Mediterranean mountains. Prog. Phys Geogr., vol. 30.

IGME. 1970. Geological map of Greece. Tsepelovon sheet; $1: 50,000$. Athens, Institute of Geological and Mineral Exploration.

Imbrie, J.; Hays, J. D.; Martinson, D. G.; McIntyre, A.; Mix, A. C.; Morley, J. J.; Pisias, N. G.; Prell, W. L.; and Shackleton, N. J. 1984. The orbital theory of Pleis- 
tocene climate: support from a revised chronology of the marine ${ }^{18} \mathrm{O}$ record. In Berger, A.; Imbrie, J.; Hays, G.; Kukla, G.; and Saltzman, B. eds. Milankovitch and climate. Dordrecht, Reidel, p. 269-306.

Jaurand, E. 1994. Les heritages glaciaire de l'Appenin. $\mathrm{PhD}$ thesis, Université de Paris 1 Panthéon Sorbonne. $600 \mathrm{p}$.

Kotarba, A.; Hercman, H.; and Dramis, F. 2001. On the age of Campo Imperatore glaciations, Gran Sasso Massif, central Italy. Geogr. Fis. Dinam. Quat. 24:65-69.

Lewin, J.; Macklin, M. G.; and Woodward, J. C. 1991. Late Quaternary fluvial sedimentation in the Voidomatis basin, Epirus, northwest Greece. Quat. Res. 35: 103-115.

Martinson, D. G.; Pisias, N. G.; Hays, J. D.; Imbrie, J.; Moore, T. C.; and Shackleton, N. J. 1987. Age dating and the orbital theory of the ice ages: development of a high-resolution 0-300,000 year chronostratigraphy. Quat. Res. 27:1-29.

Mastronuzzi, G.; Sanso, P.; and Stamatopoulos, L. 1994. Glacial landforms of the Peloponnisos (Greece). Riv. Geogr. Ital. 101:77-86.

Mercer, D. C. 1963. Cambridge expedition to the Pindus Mountains, Greece, 1962. Cave Res. Group G.B. Newsl. 87:1-5.

Messerli, B. 1967. Die eiszeitliche und die gegenwartige Vertgletscherung im Mittelemeeraum. Geogr. Helv. 22:105-228.

Mistardis, G. 1952. Recherches glaciologiques dans les parties supérieures des Monts Oeta et Oxya /Grèce centrale). Z. Gletsch. Glazialgeol. 2:72-79.

Niculescu, C. 1915. Sur les traces de glaciation dans le massif Smolica (chaine du Pinde meridional). Bull. Sect. Sci. Acad. Roumaine 3:146-151.

Ninkovich, D., and Shackleton, N. J. 1975. Distribution, stratigraphic position and age of ash " $\mathrm{L}$ ", in the Panama Basin region. Earth Planet. Sci. Lett. 27:20-34.

Palmentola, G.; Boenzi, F.; Mastronuzzi, G.; and Tromba, F. 1990. Osservazioni sulle tracce glaciali del M. Timfi, catena del Pindo (Grecia). Geogr. Fis. Dinam. Quat. 13:165-170.

Pechoux, P. Y. 1970. Traces of glacial action in the mountains of central Greece. Rev. Geogr. Alpine 58:211224.

Sestini, A. 1933. Tracce glaciali sul Pindo epirota. Boll. Reale Soc. Geogr. Ital. 10:136-156.

Shackleton, N. J., and Pisias, N. G. 1985. Atmospheric carbon dioxide, orbital forcing, and climate. In Sundquist, E. T., and Broecker, W. S., eds. The carbon cycle and atmospheric $\mathrm{CO}_{2}$ : natural variations archean to the present. Am. Geophys. Union Monogr. 32:303317.

Shakesby, R. A. 1997. Pronival (protalus) ramparts: a review of forms, processes, diagnostic criteria and palaeoenvironmental implications. Prog. Phys. Geogr. 21:394-418.

Sibrava, V.; Bowen, D. Q.; and Richmond, G. M., eds. 1986. Quaternary glaciations in the Northern Hemisphere. Quat. Sci. Rev., vol. 5.

Smart, P. L. 1991. Uranium series dating. In Smart, P. L., and Frances, P. D., eds. Quaternary dating methods: a user's guide. Technical guide no. 4. Quat. Res. Assoc. p. $45-83$.

Smith, G. R.; Woodward, J. C.; Heywood, D. I.; and Gibbard, P. L. 2000. Interpreting glacial features from SPOT HRV data using fuzzy techniques. Comput. Geosci. 26:479-490.

Smith, G. W.; Nance, R. D.; and Genes, A. N. 1997. Quaternary glacial history of Mount Olympus. Geol. Soc. Am. Bull. 109:809-824.

Sweeting, M. 1972. Karst landforms. London, Macmillan. p. 263-269.

Tzedakis, P. C. 1994. Vegetation change through glacialinterglacial cycles: a long pollen sequence perspective. Philos. Trans. R. Soc. Lond. B 345:403-432.

Tzedakis, P. C.; Andrieu, V.; de Beaulieu, J. L.; Crowhurst, S.; Follieri, M.; Hooghiemstra, H.; Magri, D.; et al. 1997. Comparison of terrestrial and marine records of changing climate of the last 500,000 years. Earth Planet. Sci. Lett. 150:171-176.

Tzedakis, P. C.; Lawson, I. T.; Frogley, M. R.; Hewitt, G. M.; and Preece, R. C. 2002. Buffered tree population changes in a Quaternary refugium: evolutionary implications. Science 297:2044-2047.

Tzedakis, P. C.; McManus, J. F.; Hooghiemstra, H.; Oppo, D. W.; and Wijmstra, T. A. 2003. Comparison of changes in vegetation in northeast Greece with records of climate variability on orbital and suborbital frequencies over the last 450,000 years. Earth Planet. Sci. Lett. 212:197-212.

van Andel, T. H. 1998. Paleosols, red sediments, and the Old Stone Age in Greece. Geoarchaeology 13:361-390.

van Calsteren, P., and Schwieters, J. B. 1995. Performance of a thermal ionisation mass spectrometer with a deceleration lens system and post-deceleration detector selection. Int. J. Mass Spectrom. Ion Proc. 146/147: 119-129.

van der Wiel, A. M., and Wijmstra, T. A. 1987a. Palynology of the lower part $(78-120 \mathrm{~m})$ of the core Tenaghi Philippon. II. Middle Pleistocene of Macedonia, Greece. Rev. Palaeobot. Palynol. 52:73-88.

. 1987b. Palynology of 112.8-197.8 m interval of the core Tenaghi Philippon. III. Middle Pleistocene of Macedonia, Greece. Rev. Palaeobot. Palynol. 52:89117.

Waltham, A. C. 1978. The caves and karst of Astraka, Greece. Trans. Br. Cave Res. Assoc. 5:1-12.

Wijmstra, T. A. 1969. Palynology of the first 30 metres of a 120-m deep section in northern Greece. Acta Bot. Neerl. 18:511-527.

Wijmstra, T. A., and Groenhart, M. C. 1983. Record of 700,000 years vegetational history in eastern Macedonia (Greece). Rev. Acad. Colomb. Cienc. Exactas Fis. Nat. 15:87-98.

Wijmstra, T. A., and Smit, A. 1976. Palynology of the middle part (30-78 metres) of the $120 \mathrm{~m}$ deep section in northern Greece (Macedonia). Acta Bot. Neerl. 25: 297-312.

Woodward, J. C.; Lewin, J.; and Macklin, M. G. 1992. Alluvial sediment sources in a glaciated catchment: 
the Voidomatis basin, northwest Greece. Earth Surf. Proc. Land. 16:205-216.

1995. Glaciation, river behaviour and the Palaeolithic settlement of upland northwest Greece. In Lewin, J.; Macklin, M. G.; and Woodward, J. C., eds. Mediterranean Quaternary river environments. Rotterdam, Balkema, p. 115-129.

Woodward, J. C.; Macklin, M. G.; and Lewin, J. 1994. Pedogenic weathering and relative-age dating of Qua- ternary alluvial sediments in the Pindus Mountains of northwest Greece. In Robinson, D. A., and Williams, R. B. G., eds. Rock weathering and landform evolution. Chichester, Wiley, p. 259-283.

Woodward, J. C.; Macklin, M. G.; and Smith, G. R. 2004. Pleistocene glaciation in the mountains of Greece. In Ehlers, J., and Gibbard, P. L., eds. Quaternary glaciations: extent and chronology. Pt. I. Europe. Amsterdam, Elsevier, p. 155-173. 